\title{
Evidence summary: The relationship between oral diseases and diabetes
}

Francesco D’Aiuto, David Gable, Zahra Syed, Yasmin Allen, Kristina L Wanyonyi, Sandra White, Jenny Gallagher

Dr Francesco D'Aiuto

Reader in Periodontology

Head of Periodontology

Eastman Dental Institute

256 Grays Inn Road

London

WC1X 8LD

Email: f.daiuto@ucl.ac.uk

Dr David Gable

Consultant Diabetes and Endocrinology

Imperial College Healthcare NHS Trust

Diabetes and Endocrinology

$1^{\text {st }}$ Floor Mint Wing

St Mary's Hospital

Praed Street

Paddington

W2 1NY

Email: David.Gable@imperial.nhs.uk

Dr Zahra Syed

Specialist trainee in Oral Medicine

Leeds Teaching Hospital NHS Trust

Clarendon Way, Leeds LS2 9LU

Email: zsyed@nhs.net

Ms Yasmin Allen BDS PGdip

Clinical Fellow in leadership

Health Education England

Stewart house

32 Russell Square

London

WC1B 5DN

Dr Kristina L Wanyonyi

(Formerly Research Associate, King's College London Dental Institute, Population and Patient Health)

Senior Lecturer in Dental Public Health

University of Portsmouth Dental Academy

William Beatty Building, Hampshire Terrace,

Portsmouth PO1 2QG

Email: kristina.wanyonyi@port.ac.uk

Dr Sandra White

Director of Dental Public Health

Population Health \& Care Division

Health and Wellbeing Directorate

Public Health England 
Skipton House

80 London Road

London SE1 6LH

Tel: $\quad$ +44 (0) 2036820911

Mobile: 07917184998

Email: sandra.white@phe.gov.uk

Professor Jennifer E Gallagher MBE

Head of Population and Patient Health

Newland Pedley Professor of Oral Health Strategy

Honorary Consultant in Dental Public Health

King's College London Dental Institute

Denmark Hill Campus. Bessemer Road, London SE5 9RS

Email: jenny.gallagher@kcl.ac.uk

\section{Corresponding author}

Professor Jennifer E Gallagher MBE Head of Population and Patient Health

Newland-Pedley Professor of Oral Health Strategy

Honorary Consultant in Dental Public Health

Tel: 02032995171/3481 Admin

Email: jenny.gallagher@kcl.ac.uk 


\section{In brief}

- Current evidence suggests a number of associations between oral diseases and diabetes mellitus (diabetes)

- There is evidence that oral health care/management of oral disease, most notably periodontal care, has a short term beneficial influence on diabetes outcomes but there is no evidence that this is sustained over the long-term and/or reduces the development of the complications of diabetes

- There is limited evidence to support major changes to medical or dental therapy in the case of diagnosis of diabetes; regular periodontal/oral care may benefit patients with periodontitis and diabetes

- At present, diabetes should not be considered a diagnosis that would require a change to dental therapy, such as restricting dental implants

- A diagnosis of diabetes should be considered and excluded in those who have severe periodontitis and vice versa 


\section{Abstract}

Introduction This paper is the third of four rapid reviews undertaken to explore the relationships between oral health and general medical conditions in order to support teams within Public Health England, health practitioners and policymakers. Aims This review aimed to explore the nature of the association between poor oral health and diabetes when found in the same individuals or populations, having reviewed the most contemporary evidence in the field. Methods The reviews were undertaken by four groups each comprising consultant clinicians from medicine and dentistry, trainees, public health and academics. The methodology involved a streamlined rapid review process and synthesis of the findings. Results The results identified a number of systematic reviews of low to high quality suggesting that diabetes is associated with periodontal disease, tooth loss, and oral cancer in particular, and that the management of oral diseases, most notably periodontal care, has a short-term beneficial influence on metabolic outcomes related to diabetes; however, there is no evidence that this is sustained over the long-term and reduces the prevalence of the long-term complications. Conclusion Current evidence, of mixed quality, suggests a number of associations between oral diseases and diabetes mellitus (diabetes). Further high quality research is required in this field. 


\section{Background}

In England almost three million people have diabetes and many more are at risk of developing it. The estimated national spend by the NHS on diabetes is approximately 10 billion per year (1).

Diabetes mellitus is a long-term condition characterised by an inability to control the glucose levels in the blood due to an absolute or relative lack of the hormone insulin (International Classification of Diseases ICD-10 (E08-E13).

The majority of people with diabetes can be classified as having type 1 or type 2. Type 1 diabetes is an autoimmune disease, a group of diseases when the body's own immune system attacks the body's own host tissues rather than infections. It tends to occur at a younger age and it is essential to treat with insulin. Type 2 diabetes is 8-9 times more common than type 1 . It occurs as a result of a combination of lack of response to insulin (insulin resistance) and lack of insulin production. It tends to occur at a later age and in the early stages can be treated with oral medications.

Elevated glucose levels are associated with a number of complications including blindness, kidney failure and minor and major leg amputation which can be prevented by maintaining low glucose levels with both lifestyle change and medication. Diabetes foot disease occurs as a result of diabetic peripheral neuropathy with high glucose levels associated with a wide range of both chronic and acute neuropathies that affect the full anatomic breadth of the peripheral nervous system from the nerve root to the skin, mirroring the spectrum of peripheral nerve diseases in general (2). In addition diabetes is associated with an increased risk of vascular complications such as myocardial infarction, stroke and peripheral vascular disease (3). Obesity is a strong risk factor for the development and progression of diabetes. Indeed the increased incidence of overweight and obesity worldwide explains the ever increasing number of people affected by type 2 diabetes (4).

It is preferable to view type 1 and 2 diabetes as separate conditions. Where evidence is in a particular type of diabetes this is indicated. For the purpose of this review we have used the term diabetes alone when the population studied is mixed, undifferentiated or not classified in the original article. In general, the majority of patients in the studies reviewed would be expected to have type 2 diabetes as it is more common.

The two most common diseases affecting oral health are dental caries and periodontitis. Dental caries (caries) is the localised destruction of susceptible dental hard tissues by acidic by-products from bacterial fermentation of dietary carbohydrates (5). Periodontitis is a chronic inflammatory disease caused by a dysbiosis of the sub-gingival microflora and resulting in the loss of the tissues surrounding the teeth (6). Approximately half of all adults in the UK are affected by some level of irreversible periodontitis, which increases with age, and almost a third of the same population have obvious dental decay (7).

Both type 1 and 2 diabetes have been associated with many oral diseases in the past. Observational studies have suggested diabetes links with periodontal diseases (including peri-implant disease), caries 
(with its risks of tooth loss), oral mucosal disease (including oral infections), oral cancer, salivary dysfunction and oral dysesthesias including taste disturbances. Further clinical studies focused on the role of oral diseases and in particular periodontal status or therapy and their effect on hyperglycaemic control as well as the role of anti-diabetic medication in oral states.

However, with all the studies investigating these associations there has been little consensus with respect to the overall effect of diabetes mellitus on oral health and vice versa. This has made it difficult for both dental and medical clinicians alike to advise patients on these issues with great confidence. By pooling together the facts from high quality evidence-based research in one place, this paper should provide a source for clinicians to give this advice confidently.

\section{Review methods}

A rapid review of articles published between 2005 and 2015 investigating the relationship between diabetes and oral health was performed. A rapid review is a synthesis of the most current and best evidence to inform decision-makers (8). It combines elements of systematic reviews with a streamlined approach to summarise available evidence in a timely manner.

Search syntax was developed based on subject knowledge, MeSH terms and task group agreements (Figure 1); followed by duplicate systematic title and abstract searches of three electronic databases: Cochrane, PubMed, OVID (Embase, MEDLINE (R), and PsycINFO). Inclusion criteria were systematic reviews/meta-analyses involving diabetes and oral health, published in the 10-year period, involving human research and the full text being available in English. Exclusion criteria included animal studies and only systematic reviews and/or meta-analyses of observational and experimental studies were included in the final results.

Two independent searches were undertaken, screening papers by title and abstract for relevance and duplication. Each researcher reviewed their search results and excluded papers that were not systematic reviews/meta-analyses, were not related to diabetes and any aspect of oral health, and were not available in English despite contacting the authors. After the final selection the searches were combined and duplicates removed. Both researchers discussed included and excluded papers and a final agreement was made on the papers to be included for the rapid review. A flow diagram of the process is shown in Figure 2.

\section{Figure 2}

The following information was extracted from each paper: author, year, title, journal, population studied, oral disease/intervention, definitions used, methods, comparison/intervention and controls, outcomes, results, authors' conclusions, quality and quality justification; all shown in the data extraction table. From a total of 2,406 papers initially identified, there were 30 articles identified by the review for inclusion (Table 1). Key findings from the rapid review extracted from the information above are shown below, with examples of the papers that provide evidence for the results synthesis. Each of the relevant oral 
health conditions, and relevant therapy, are considered in turn below starting with periodontitis and its management.

\section{Table 1}

Quality assessment was undertaken for each systematic review using the PRISMA and AMSTAR tools to ascertain risk of bias. An AMSTAR assessment was carried out on all papers with the methodological quality of the review being rated as "High" with a score between eleven and eight, "Moderate" between seven and four, and "Low" between four and zero. The quality of all papers was confirmed by group discussion.

The quality of the systematic reviews identified varied. Of the 30 systematic reviews, 12 were deemed to be of high quality, 15 of moderate quality and three were of low quality (Table 1). Common AMSTAR quality issues were a) lack of a priori design or question, b) no quality appraisal, c) missing tables, and d) no duplicate study selection.

Within the theme identified by this review, reviews related to investigation of i] glycaemic control and periodontal therapy and ii] the risk of oral cancer in patients with diabetes were of high quality, whilst articles on the association between dental implant therapy $(9,10)$, osseo-integration (11) and diabetic neuropathy (12), with oral diseases or therapy were of low quality.

\section{Results: evidence synthesis}

The results are reported in nine sections, each relating to an oral disease or condition investigated. Each section contains evidence of any association between the oral disorder and diabetes and also on the impact of oral therapy on diabetes and diabetes management on oral health.

\section{1] Periodontitis and diabetes}

There is high quality evidence that diabetes (type 2 ) is a risk factor for periodontitis (13). There is some moderate quality evidence that whilst the extent of periodontitis, i.e. percentage of surfaces/sites affected is similar between patients with or without diabetes, measures of severity including greater clinical attachment loss and pocket probing depths are greater in patients with diabetes (14). Patients with diabetic complications, most specifically diabetic neuropathy, appear to have poorer oral health, including periodontitis, than those without neuropathy (12). However, there is scant evidence from two reviews of variable quality that diagnosis of periodontitis a) promotes development of type 2 diabetes and b) adversely affects glycaemic control and diabetes complications in patients with diabetes (12, $15)$.

In summary, whilst there is strong evidence that diabetes is a recognized risk factor for periodontitis, more research is needed to ascertain the impact of periodontitis on the development and progression of diabetes. 
II] Periodontal therapy and glycaemic control

One high quality systematic review provides evidence that in patients with type 2 diabetes, intensive periodontal therapy involving scaling and root planning reduced $\mathrm{HbA} 1 \mathrm{c}$ (a marker of glycaemic control) by $0.29 \%$ [3-4 mmol/l] for up to three months; however, after six months there was no evidence that this reduction was sustained (16). Modest improvements in glycaemic control, as demonstrated by a reduction in $\mathrm{Hb} 1 \mathrm{Ac}$, are supported by seven other moderate quality systematic reviews (15, 17-22); whilst one was equivocal (23). In one of the reviews by Wang et al 2014, after three months follow-up, periodontal treatment substantially lowered $\mathrm{HbA} 1 \mathrm{c}$ compared with no treatment $(-0.36 \%, 95 \% \mathrm{Cl}$, $0.52 \%$ to $0.19 \%, P<0.0001)$. These findings were accompanied by substantial and statistically significant reductions in PPD and CAL between study groups (PPD $0.42 \mathrm{~mm}, 95 \% \mathrm{Cl}: 0.60$ to 0.23 , $\mathrm{P}<0.00001$; CAL $0.34 \mathrm{~mm}, 95 \% \mathrm{Cl}: 0.52$ to $0.16, \mathrm{P}=0.0002$ ). Consistent with the 2015 Cochrane review, there was no substantial change of $\mathrm{HbA} 1 \mathrm{c}$ levels after 6 months (21).

In summary, there is merit in performing periodontal therapy in patients with type 2 diabetes with regards to a short term improvement in metabolic control. Further research is needed to demonstrate that this benefit is sustained over longer follow-up and it translates into reduction of diabetes complications.

\section{III] Periodontal therapy and systemic/surrogate markers}

One high quality review suggests that periodontal treatment (SRP) reduced markers of systemic inflammation in patients with diabetes: serum levels of TNF- $\alpha$ and CRP (24). Sgolastra et al, 2013 (19) reported no significant improvements in lipid fractions (total cholesterol, triglycerides and high and low density lipoprotein cholesterol [TC, TG, HDL, or LDL]) in patients with diabetes and chronic periodontitis who received scaling and root planning (19).

Lastly, five different reviews suggest that different types of periodontal treatment; surgical or nonsurgical, with or without the use of adjunctive antibiotics, antiseptics, or oral hygiene instructions do not appear to produce different effects on glycaemic control in patients with diabetes $(16,17,20,21,25)$.

\section{IV] Tooth loss and diabetes}

Patients with diabetic complications, most specifically diabetic neuropathy, appear to have more tooth loss than those without neuropathy (12). This finding is consistent with the view that diabetes and its complications are associated with poorer oral health.

\section{V] Caries and diabetes}

Conflicting evidence on the association between diabetes and increased prevalence of caries was found. Greater levels of dental plaque were noted in patients with diabetes and this may have implications for future risk of caries (26). Furthermore, children with type 1 diabetes are at increased risk of periodontal diseases as evidenced by greater dental plaque levels, gingival inflammation and bleeding. 


\section{VI] Dental Implants and diabetes}

There is limited evidence that poor metabolic control is associated with peri-implant disease $(27,28)$, and weak evidence of higher marginal bone loss around dental implants in patients with diabetes with unspecified metabolic control (9). There is equivocal evidence that patients with diabetes have higher failure rates of dental implants and no evidence that diabetes is a contraindication to dental implant placement $(10,11,29)$; however, some evidence for delay in implant osteo-integration based on glycaemic control was identified (Oates et al., 2013).

\section{VII] Oral surgery and diabetes}

Whilst there is evidence that people with diabetes are more likely to suffer complications of surgery in other areas, specific evidence that diabetes is associated with post-operative complications in the oral cavity is lacking (30).

\section{VIII] Oral squamous cell carcinoma and diabetes}

A high quality systematic review suggests that type 2 diabetes is associated with an elevated risk of oral cancer and precancerous lesions (31). Patients with type 2 diabetes have a higher case mortality on diagnosis of oral cancer, independent of tobacco, alcohol and obesity factors with a relative risk of $1.41(95 \% \mathrm{Cl}: 1.16-1.72)$ when comparing patients with diabetes to people without diabetes, with no evident heterogeneity among studies (31).

\section{IX] Saliva and diabetes}

Patients with diabetic complications, most specifically diabetic neuropathy, appear to have greater mouth dryness than controls (12). There is limited evidence on the role of diabetes in increasing the risk of salivary dysfunction (32). There is some recent, limited and weak evidence that salivary protein markers may be used to monitor glycaemic control accurately as a less painful alternative to capillary blood glucose measurements (33).

\section{Summary}

The evidence reviewed to form the conclusions for this rapid review demonstrates that there are oral manifestations of diabetes, including effects on oral health, periodontitis, oral cancer risk, and that diabetes may have an effect on dental implants success. More evidence is required before advising clinicians of any contraindications to perform implants in diabetic patients. There is strong evidence of type 2 diabetes being a risk factor for periodontal diseases and weak evidence in relation to type 1. There is weak evidence in relation to dental caries experience in children. Limited evidence exists of periodontitis being a risk factor for diabetes; however, there is a growing body of evidence that professional periodontal treatment (ie scaling and root planning as a minimum) results in modest improvement in glycaemic control in the short-term but this is not sustained beyond three months. Furthermore, the average reduction in glycated haemoglobin observed following periodontal therapy $(0.3 \% / 3-4 \mathrm{mmol} / \mathrm{mol})$ could translate into long-term clinical benefits but further research is needed. 
Overall, there is some evidence of a bidirectional relationship between diabetes and oral health and the management of conditions, most notably for periodontitis on diabetes. This is a very important area for further interdisciplinary patient care and research, particularly as health professionals care for an ageing population with multiple co-morbidities. As dental professionals we need to keep abreast of the emerging evidence of associations between non-communicable diseases. Whilst there is no evidence to support a major change in patient management we should be aware that regular periodontal care may benefit patients with periodontitis and diabetes. However, patients with periodontitis need help with regular self-care and professional periodontal treatment.

The rapid nature of the review is a potential limitation especially with the large scope of the topic reviewed. However, the methodology used has been proven successful previously in work by Khangura et al., $(8,34)$.This rapid review was limited by the quality of the systematic reviews and meta-analyses appraised. These limitations are well summarised in the Cochrane review studies by Simpson et al (2010 and updated in 2015) (16,35), and highlighted in Table 1. Overall the quality of the reviews in this field was mixed whilst the research on the topic was generally judged to be of low quality.

It is important to note that the publications do not use standard definitions and classification of periodontitis as used by the American guidelines (6); this should be standardised in future to facilitate comparability between studies.

There is evidence that management of oral disease, most notably periodontal care, has a short term beneficial influence on diabetes but no evidence that this is sustained over the long-term and reduces diabetes complications. The vast majority of the articles described define diabetes only by its presence or absence and many do not even classify which type of diabetes was present. There was no information regarding the effect of different levels of glucose control on either the absence of presence of an association of if the association has a glucose exposure "dose effect". Testing the association of HBa1c and dental outcomes would therefore be useful future research. Ideally, type 1 and 2 diabetes they should be studied separately given the above. More high quality multidisciplinary research is needed to investigate relations between the non-communicable diseases and their management as shown in Table 2.

\section{Table 2}

In summary, the current evidence suggests a number of associations between oral diseases and diabetes. There is limited evidence to support major changes to medical or dental therapy; however, regular periodontal/oral care may benefit glycaemic control in patients with periodontitis and diabetes. At present, diagnosis of diabetes should not require a change to dental therapy, such as restricting use of dental implants. Greater awareness of the impact of diabetes on oral health and vice versa is needed among medical and dental health professionals. 


\section{Acknowledgement}

We would like to acknowledge the support of Public Health England, the Royal College of Surgeons and the British Dental Association. 
1. National Health Service. Five year forward view2014 11/11/2014. Available from: http://www.england.nhs.uk/wp-content/uploads/2014/10/5yfv-web.pdf.

2. Bullon P, Newman HN, Battino M. Obesity, diabetes mellitus, atherosclerosis and chronic periodontitis: a shared pathology via oxidative stress and mitochondrial dysfunction? Periodontol 2000. 2014;64(1):139-53.

3. King P, Peacock I, Donnelly R. The UK prospective diabetes study (UKPDS): clinical and therapeutic implications for type 2 diabetes. Br J Clin Pharmacol. 1999;48(5):643-8.

4. Eckel RH, Kahn SE, Ferrannini E, Goldfine AB, Nathan DM, Schwartz MW, et al. Obesity and Type 2 Diabetes: What Can Be Unified and What Needs to Be Individualized? Diabetes care. 2011;34(6):1424-30.

5. Fejerskov O, Kidd E. Dental caries: the disease and its clinical management: John Wiley \& Sons; 2009.

6. Eke PI, Page RC, Wei L, Thornton-Evans G, Genco RJ. Update of the case definitions for population-based surveillance of periodontitis. Journal of periodontology. 2012;83(12):1449-54.

7. Steele J, O'Sullivan I. Adult Dental Health Survey2011 21/05/2011. Available from: http://www.hscic.gov.uk/catalogue/PUB01061/adul-dent-heal-surv-firs-rele-2009-rep.pdf.

8. Khangura S, Konnyu K, Cushman R, Grimshaw J, Moher D. Evidence summaries: the evolution of a rapid review approach. Syst Rev. 2012;1:10.

9. Oates TW, Huynh-Ba G, Vargas A, Alexander P, Feine J. A critical review of diabetes, glycemic control, and dental implant therapy. Clinical Oral Implants Research. 2013;24(2):117-27.

10. Bornstein MM, Cionca N, Mombelli A. Systemic conditions and treatments as risks for implant therapy. Int J Oral Maxillofac Implants. 2009;24 Suppl:12-27.

11. Mombelli A, Cionca N. Systemic diseases affecting osseointegration therapy. Clinical Oral Implants Research. 2006;17:97-103.

12. Borgnakke WS, Anderson PF, Shannon C, Jivanescu A. Is There a Relationship Between Oral Health and Diabetic Neuropathy? Current diabetes reports. 2015;15(11):1-9.

13. Chavarry NG, Vettore MV, Sansone C, Sheiham A. The relationship between diabetes mellitus and destructive periodontal disease: a meta-analysis. Oral Health Prev Dent. 2009;7(2):10727.

14. Khader YS, Dauod AS, El-Qaderi SS, Alkafajei A, Batayha WQ. Periodontal status of diabetics compared with nondiabetics: a meta-analysis. Journal of Diabetes and its Complications. 2006;20(1):59-68.

15. Borgnakke WS, Ylostalo PV, Taylor GW, Genco RJ. Effect of periodontal disease on diabetes: systematic review of epidemiologic observational evidence. J Periodontol. 2013;84(4 Suppl):S135-52. 16. Simpson TC, Weldon JC, Worthington HV, Needleman I, Wild SH, Moles DR, et al. Treatment of periodontal disease for glycaemic control in people with diabetes mellitus. Cochrane Database Syst Rev. 2015;11:Cd004714.

17. Engebretson S, Kocher T. Evidence that periodontal treatment improves diabetes outcomes: a systematic review and meta-analysis. J Periodontol. 2013;84(4 Suppl):S153-69.

18. Li Q, Hao S, Fang J, Xie J, Kong XH, Yang JX. Effect of non-surgical periodontal treatment on glycemic control of patients with diabetes: a meta-analysis of randomized controlled trials. Trials. 2015;16:291.

19. Sgolastra F, Severino M, Pietropaoli D, Gatto R, Monaco A. Effectiveness of periodontal treatment to improve metabolic control in patients with chronic periodontitis and type 2 diabetes: a meta-analysis of randomized clinical trials. J Periodontol. 2013;84(7):958-73.

20. Teeuw WJ, Gerdes VE, Loos BG. Effect of periodontal treatment on glycemic control of diabetic patients: a systematic review and meta-analysis. Diabetes Care. 2010;33(2):421-7. 
21. Wang TF, Jen IA, Chou C, Lei YP. Effects of periodontal therapy on metabolic control in patients with type 2 diabetes mellitus and periodontal disease: a meta-analysis. Medicine (Baltimore). 2014;93(28):e292.

22. Sun $Q$, Feng $M$, Zhang $M$, Zhang $Y$, Cao $M$, Bian $L$, et al. Effects of periodontal treatment on glycaemic control in type 2 diabetes patients; a meta-analysis of randomised controlled trials. Chinese Journal of Physiology. 2014;57(6):305-14.

23. Mauri-Obradors E, Jane-Salas E, Sabater-Recolons Mdel M, Vinas M, Lopez-Lopez J. Effect of nonsurgical periodontal treatment on glycosylated hemoglobin in diabetic patients: a systematic review. Odontology. 2015;103(3):301-13.

24. Artese HPC, Foz AM, Rabelo MD, Gomes GH, Orlandi M, Suvan J, et al. Periodontal Therapy and Systemic Inflammation in Type 2 Diabetes Mellitus: A Meta-Analysis. Plos One. 2015;10(5):14.

25. Corbella S, Francetti L, Taschieri S, De Siena F, Fabbro MD. Effect of periodontal treatment on glycemic control of patients with diabetes: A systematic review and meta-analysis. Journal of Diabetes Investigation. 2013;4(5):502-9.

26. Ismail AF, McGrath CP, Yiu CKY. Oral health of children with type 1 diabetes mellitus: A systematic review. Diabetes Research and Clinical Practice. 2015;108(3):369-81.

27. Heitz-Mayfield LJA. Peri-implant diseases: diagnosis and risk indicators. Journal of Clinical Periodontology. 2008;35:292-304.

28. Javed F, Romanos GE. Impact of Diabetes Mellitus and Glycemic Control on the Osseointegration of Dental Implants: A Systematic Literature Review. Journal of Periodontology. 2009;80(11):1719-30.

29. Chen H, Liu N, Xu X, Qu X, Lu E. Smoking, radiotherapy, diabetes and osteoporosis as risk factors for dental implant failure: a meta-analysis. PLoS One. 2013;8(8):e71955.

30. Barasch A, Safford MM, Litaker MS, Gilbert GH. Risk factors for oral postoperative infection in patients with diabetes. Spec Care Dentist. 2008;28(4):159-66.

31. Gong Y, Wei B, Yu L, Pan W. Type 2 diabetes mellitus and risk of oral cancer and precancerous lesions: a meta-analysis of observational studies. Oral Oncol. 2015;51(4):332-40.

32. Morais EFd, Macedo RAdP, Lira JAdS, Lima KCd, Borges BCD. Factors related to dry mouth and low salivary flow rates in diabetic elderly: a systematic literature review. Revista Brasileira de Geriatria e Gerontologia. 2014;17:417-23.

33. Mascarenhas P, Fatela B, Barahona I. Effect of Diabetes Mellitus Type 2 on Salivary GlucoseA Systematic Review and Meta-Analysis of Observational Studies. 2014.

34. Khangura S, Konnyu K, Cushman R, Grimshaw J, Moher D. Evidence summaries: the evolution of a rapid review approach. Systematic reviews. 2012;1(1):1-9.

35. Simpson TC, Weldon JC, Worthington HV, Needleman I, Wild SH, Moles DR, et al. Treatment of periodontal disease for glycaemic control in people with diabetes mellitus. Cochrane Database of Systematic Reviews. 2012;2015(11):Art. No.: CD004714. DOI: 10.1002/14651858.CD004714.pub3. 


\section{Tables and figures}

\section{Appendix 1 Search terms}

1. ral health and hba1c/ifcc /glycaemic index

2. oral disease hba1c/ifcc /glycaemic index

3. mouth and diabetes mellitus

4. oral manifestations and diabetes mellitus

5. gingival or gingivitis and diabetes mellitus oral surgery complications and diabetes mellitus

6. head and neck complications and diabetes mellitus hyposalivation / xerostomia / dry mouth and diabetes mellitus

7. salivary gland disease and diabetes mellitus

8. taste disturbance / dysguesia and diabetes mellitus

9. oral dysaesthesia and diabetes mellitus

10. halitosis and diabetes mellitus

11. oral ulcers or oral ulceration and diabetes mellitus recurrent aphthous stomatitis and diabetes mellitus

12. oral lichen planus and diabetes mellitus

13. oral cancer and diabetes mellitus

14. oral squamous cell carcinoma and diabetes mellitus

15. oral actinomycosis and diabetes mellitus

16. streptococcus viridans and diabetes mellitus

17. oral mycobacterial or (oral mycobacterium) and diabetes mellitus

18. oral tuberculosis and diabetes mellitus

19. oral viral / virus and diabetes mellitus

20. oral syphillis and diabetes mellitus

21. oral hsv or oral herpes simplex or type 1 hsv or type 1 (herpes simplex) and diabetes mellitus

22. oral infections and diabetes mellitus

23. oral candida or oral candidosis or oral candidiasis and diabetes mellitus

24. oral streptococcus and diabetes mellitus

25. oral hpv or oral human papilloma virus and diabetes mellitus

26. oral staphylococcal/ staphylococcus aureus and diabetes mellitus

27. angular cheilitis and diabetes mellitus

28. mouth disease and diabetes mellitus

29. oral protozoa and diabetes mellitus

30. (mouth or oral or dent\$).

31. (periodont $\$$ or gum $\$$ or ging $\$$ )

32. (decay or caries or cavity)

33. (plaque or biofilm)

34. (toothbrushing or tooth brushing)

35. (mouthwash or mouth wash or chlorohexidine or chx)

36. (tooth loss or edentulous or shortened dental arch)

37. (loose tooth or loose teeth)

38. dentures

39. dry socket or alveolar osteitis or non-healing socket or non-healing socket

40. xerostomia or dry mouth or hyposalivation

41. hypersalivation.mp.

42. bms or burning mouth syndrome or oral dysasthesia or burning sensation

43. minor oral surgery or tooth extraction or dental extraction

44. oral or dent $\$$ or mouth or recurrent apthous and ulcer $\$$ or stomatitis or ras

45. angular chelitis or angular stomatitis

46. dental implant\$

47. gum inflammation.mp.

48. oral or dental or socket and healing or non-healing

49. diabetes or diabetes mellitus or oral diabetes or non insulin dependent diabetes or insulin dependent diabetes or niddiabetes mellitus or iddiabetes mellitus or type 1 diabetes or type 2 diabetes

50. blood glucose or glycemic control or glycaemic control or blood glucose levels or hypoglycaemia or hyperglycaemia or glycemic index or glycaemic index

51. ifcc or hba1 or hba1c or a1c

52. insulin resista\$

53. bleeding gums.mp. 
54. oral thrush or candidia $\$$ or fung $\$$

55. tongue or mouth or lips or swallowing or pharynx or oropharynx or throat or teeth

56. lichen planus or lichenoid

57. calculus or tartar

58. chronic inflammation or acute inflammation

59. resistance to infection.mp.

60. toothache or tooth ache or tooth pain or dental pain

61. bad breath or halitosis

62. oral and white or red

63. saliv\$ gluc\$ level\$

64. antifungal $\$$ or antibacterial\$

65. tooth or dental and eruption

66. systematic review $\$$ or meta ana $\$$ or meta-ana $\$$

67. saliva 
Figure 2 Flow diagram

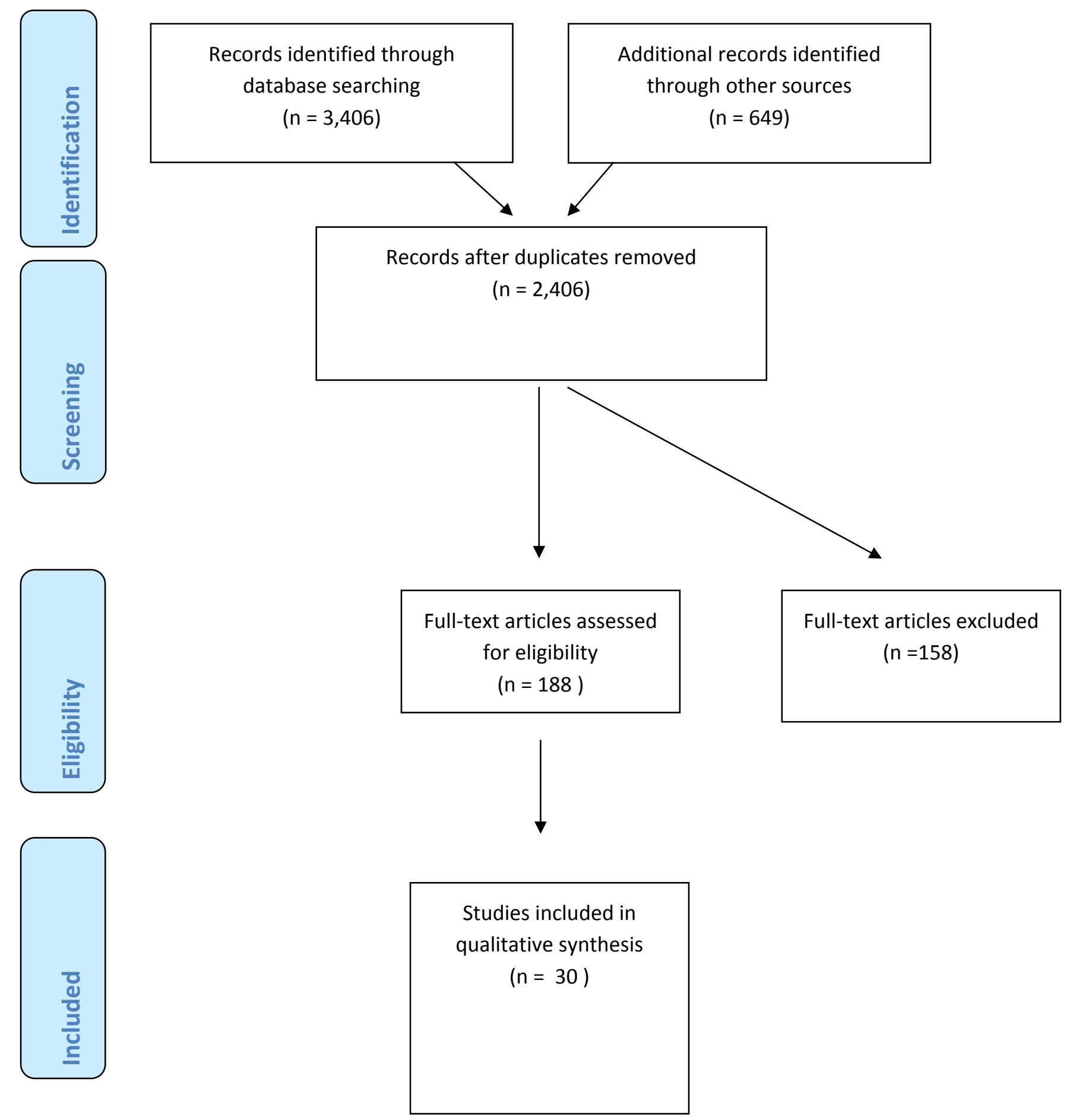

Table 1 Included papers 


\begin{tabular}{|c|c|c|c|c|c|c|c|}
\hline $\begin{array}{l}\text { Author, year } \\
\text { and } \\
\text { paper title }\end{array}$ & $\begin{array}{l}\text { Study } \\
\text { types in } \\
\text { the review }\end{array}$ & $\begin{array}{l}\text { Character- } \\
\text { istic of } \\
\text { populations }\end{array}$ & $\begin{array}{l}\text { Oral disease and } \\
\text { diagnostic criteria or } \\
\text { oral disease } \\
\text { intervention and } \\
\text { description }\end{array}$ & $\begin{array}{l}\text { Intervention/comparison } \\
\text { including covariates } \\
\text { adjusted }\end{array}$ & Results & Authors Conclusions & $\begin{array}{l}\text { AMSTAR rating } \\
\text { and justification }\end{array}$ \\
\hline $\begin{array}{l}\text { Artese et al. } \\
2015^{25} \\
\text { Periodontal } \\
\text { therapy and } \\
\text { systematic } \\
\text { inflammation in } \\
\text { type } 2 \text { diabetes } \\
\text { mellitus }\end{array}$ & $\begin{array}{l}9 \text { studies } \\
-6 \text { RCTs } \\
-2 \text { CCTs }\end{array}$ & $\begin{array}{l}\text { - Participants } \\
\text { with type } 2 \\
\text { diabetes } \\
\text { according to } \\
\text { the WHO } \\
\text { criteria } \\
\text { - Participants } \\
\text { having } \\
\text { received PT } \\
\text { with at least } \\
3 \text { months of } \\
\text { follow-up } \\
\text { - assessment } \\
\text { of serum } \\
\text { inflamm- } \\
\text { atory } \\
\text { biomarkers } \\
\text { related to } \\
\text { insulin } \\
\text { resistance; } \\
\text { and } \\
\text { - At least } 30 \\
\text { individuals } \\
\text { included in } \\
\text { the type } 2 \\
\text { diabetes } \\
\text { group }\end{array}$ & $\begin{array}{l}\text { Periodontitis: any } \\
\text { periodontitis diagnosis } \\
\text { definition proposed by } \\
\text { Authors: Includes } \\
\text { attachment level and } \\
\text { probing depths } \\
\text { Periodontal } \\
\text { interventions } \\
\text { oral hygiene } \\
\text { instructions; full-mouth } \\
\text { scaling and root planing } \\
\text { (supra/sub-gingival } \\
\text { biofilm and calculus } \\
\text { removal) (SRP); } \\
\text { surgical procedures (ie, } \\
\text { periodontal flap surgery) } \\
\text { and SRP plus local or } \\
\text { systemic antimicrobial }\end{array}$ & $\begin{array}{l}\text { Effect of periodontal therapy } \\
\text { (PT) on serum levels of } \\
\text { inflammatory markers (TNF- } \\
\text { a and CRP) in people with } \\
\text { type } 2 \text { diabetes mellitus } \\
\text { Periodontal interventions } \\
\text { were compared with the } \\
\text { passive option of no } \\
\text { periodontal treatment } \\
\text { Covariates: } \\
\text { none }\end{array}$ & $\begin{array}{l}\text { 1. Periodontal Therapy reduces } \\
\text { serum levels of inflammatory } \\
\text { markers (TNF- } \alpha \text { and CRP) in } \\
\text { Type } 2 \text { diabetic individuals. The } \\
\text { meta-analysis showed a } \\
\text { significant mean difference for } \\
\text { TNF-Alpha(- }-1.33 \mathrm{pg} / \mathrm{ml}, 95 \% \\
\mathrm{Cl} \text { : }-2.10 ;-0.56, \mathrm{p}<0.001) \text { and } \\
\mathrm{CRP}(-1.28 \mathrm{mg} / \mathrm{l}, 95 \% \mathrm{Cl} ;-0.48 \text {, } \\
\mathrm{p}<0.001) \text { favouring periodontal } \\
\text { intervention versus control) } \\
\text { 2. None of the studies reported } \\
\text { adverse effects }\end{array}$ & $\begin{array}{l}\text { 1. The results of this meta-analysis } \\
\text { support the hypothesis that PT reduces } \\
\text { serum levels of TNF- } \alpha \text { and CRP in } \\
\text { T2DM individuals } \\
\text { 2. The decrease of inflammatory } \\
\text { burden has important implications for } \\
\text { metabolic control and can, in part, } \\
\text { explain the mechanisms linking } \\
\text { periodontitis and increased risk for } \\
\text { complications in people with T2DM }\end{array}$ & $\begin{array}{l}\text { High }^{11} \\
\text { Met all Amstar } \\
\text { criteria }\end{array}$ \\
\hline
\end{tabular}




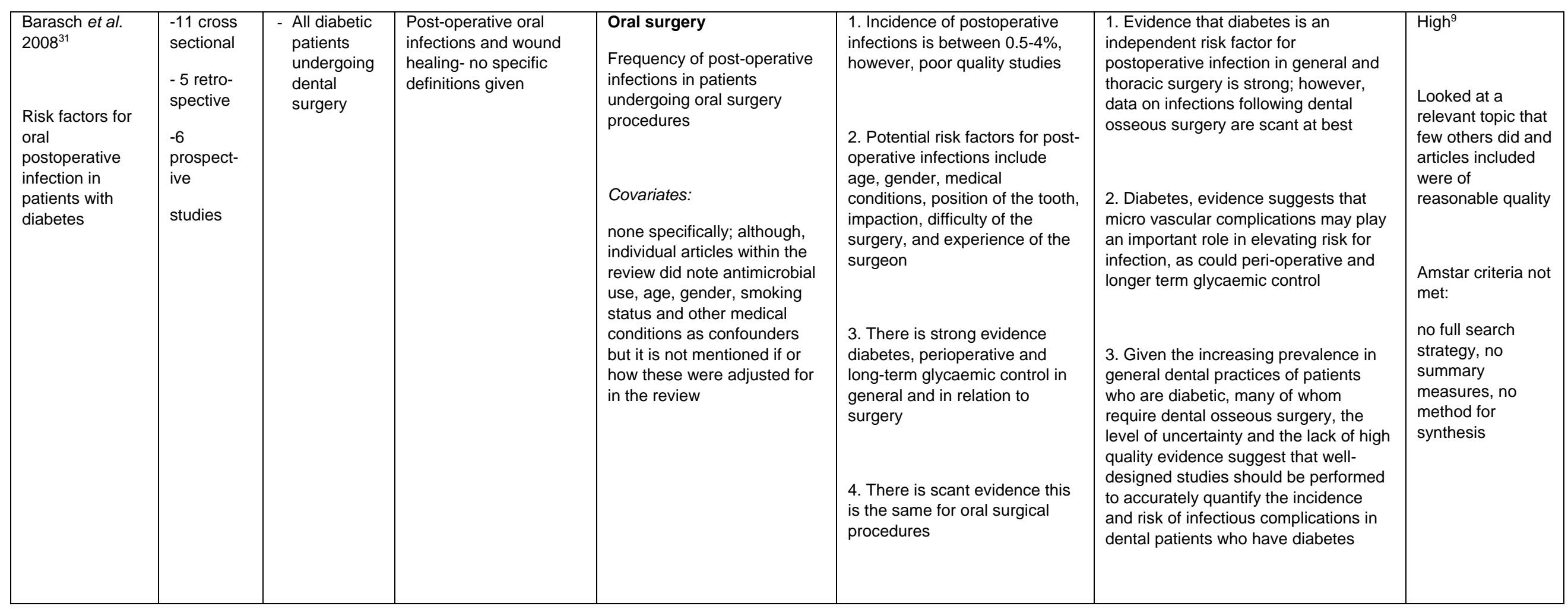




\begin{tabular}{|c|c|c|c|c|c|c|c|}
\hline $\begin{array}{l}\text { Is There a } \\
\text { Relationship } \\
\text { Between Oral } \\
\text { Health and } \\
\text { Diabetic } \\
\text { Neuropathy }\end{array}$ & $\begin{array}{l}53 \\
\text { references } \\
\text { given. } \\
\text { Type of } \\
\text { each not } \\
\text { mentioned }\end{array}$ & $\begin{array}{l}\text { Diabetic } \\
\text { patients with } \\
\text { neuropathy }\end{array}$ & $\begin{array}{l}\text { 1. Periodontal disease } \\
\text { in patients with diabetic } \\
\text { neuropathy } \\
\text { 2. Burning mouth } \\
\text { syndrome. } \\
\text { 3. Dry mouth } \\
\text { 4. Taste disturbance } \\
\text { 5. Trigeminal pain } \\
\text { 6. Temporomandibular } \\
\text { joint disorder } \\
\text { - no criteria or } \\
\text { definitions provided }\end{array}$ & $\begin{array}{l}\text { Patients' simultaneous } \\
\text { occurrence of diabetic } \\
\text { neuropathy and oral diseases } \\
\text { listed } \\
\text { Covariates: } \\
\text { none presented }\end{array}$ & $\begin{array}{l}\text { 1. High prevalence of the } \\
\text { various oral conditions in } \\
\text { people with diabetic neuropathy } \\
\text { 2. This will negatively influence } \\
\text { the quality of life } \\
\text { 3. Increased susceptibility to } \\
\text { gingivitis, periodontitis, tooth } \\
\text { loss, mouth dryness, and other } \\
\text { oral health conditions } \\
\text { 4. Periodontal infection is } \\
\text { shown to adversely affect blood } \\
\text { glucose levels } \\
5 \text {. Routine, non-surgical } \\
\text { periodontal therapy is shown to } \\
\text { be effective in decreasing } \\
\text { glycated haemoglobin levels by } \\
\text { about } 0.5 \text { percentage point } \\
\text { glycated haemoglobin, which is } \\
\text { moderate, but clinically and } \\
\text { statistically significant }\end{array}$ & $\begin{array}{l}\text { 1.There is a lack of awareness by } \\
\text { people with diabetes of increased oral } \\
\text { risks } \\
\text { 2. Periodontal infection adversely } \\
\text { affects blood glucose levels } \\
\text { 3. Periodontal therapy reduces blood } \\
\text { glucose levels by } 0.5 \% \\
\text { 4. Inter-professional management of } \\
\text { diabetes is required } \\
\text { 5. Further exploration of this } \\
\text { relationship is required } \\
\text { 6. Whether improvement of periodontal } \\
\text { health will benefit various forms of } \\
\text { neuropathy still remains to be explored } \\
\text { 7. Propose that further exploration of } \\
\text { the relationship between diabetic } \\
\text { neuropathy and oral health may result } \\
\text { in a potentially important opportunity for } \\
\text { patient-centred, inter-professional } \\
\text { collaboration for the benefit of the } \\
\text { health of the patients }\end{array}$ & $\begin{array}{l}\text { Amstar criteria not } \\
\text { met: } \\
\text { no duplicate study } \\
\text { selection, status } \\
\text { publication not an } \\
\text { inclusion criteria, } \\
\text { no comprehensive } \\
\text { literature, search, } \\
\text { no status of } \\
\text { publication, no } \\
\text { scientific quality } \\
\text { assessment, no } \\
\text { synthesis, no } \\
\text { comment on bias }\end{array}$ \\
\hline $\begin{array}{l}\text { Effect of } \\
\text { periodontal } \\
\text { disease on } \\
\text { diabetes: } \\
\text { systematic } \\
\text { review of } \\
\text { epidemiologic } \\
\text { observational } \\
\text { evidence }\end{array}$ & $\begin{array}{l}17 \text { papers: } \\
4 \text { cohort } \\
3 \text { case } \\
\text { controlled } \\
\text { not } \\
\text { presented } \\
\text { rest }\end{array}$ & $\begin{array}{l}\text { People with } \\
\text { diabetes with } \\
\text { periodontal } \\
\text { disease } \\
\text { undergoing } \\
\text { periodontal } \\
\text { therapy }\end{array}$ & $\begin{array}{l}\text { Periodontal disease and } \\
\text { therapy. No specific } \\
\text { definition in selection } \\
\text { criteria. Definitions listed } \\
\text { for individual studies }\end{array}$ & $\begin{array}{l}\text { However. reported covariates } \\
\text { adjusted for in each individual } \\
\text { study which varied includes } \\
\text { age, gender, smoking, BMI, } \\
\text { bone loss and clinical }\end{array}$ & $\begin{array}{l}\text { 1.A small body of evidence } \\
\text { supports significant, adverse } \\
\text { effects of periodontal disease } \\
\text { on glycaemic control, diabetes } \\
\text { complications, and } \\
\text { development of type } 2 \text { (and } \\
\text { possibly gestational) diabetes } \\
\text { 2.Compared to periodontally } \\
\text { healthy individuals, people with } \\
\text { poor periodontal health and } \\
\text { - type } 2 \text { diabetes, have greater } \\
\text { risk of developing poorer } \\
\text { glycaemic control }\end{array}$ & $\begin{array}{l}\text { 1.Scant current evidence suggests that } \\
\text { periodontal disease adversely affects } \\
\text { glycaemic control and diabetes } \\
\text { complications or promotes } \\
\text { development of type } 2 \text { diabetes }\end{array}$ & $\begin{array}{l}\text { Amstar criteria not } \\
\text { met: } \\
\text { no synthesis, no } \\
\text { conflict of interest } \\
\text { declared }\end{array}$ \\
\hline
\end{tabular}




\begin{tabular}{|c|c|c|c|c|c|c|c|}
\hline & & & & $\begin{array}{l}\text { attachment loss duration, } \\
\text { baseline } \mathrm{HBa} 1 \mathrm{C} \text {, etc. }\end{array}$ & $\begin{array}{l}\text { - type } 1 \text { or type } 2 \text { diabetes: } \\
\text { have greater risk for diabetes } \\
\text { related complications } \\
\text { - no diabetes: have greater risk } \\
\text { of developing manifest diabetes } \\
\text { 3. Studies on the effect of } \\
\text { periodontal disease on } \\
\text { gestational diabetes are } \\
\text { inconclusive }\end{array}$ & & \\
\hline $\begin{array}{l}\text { Bornstein et al. } \\
2009^{11} \\
\text { Systemic } \\
\text { conditions and } \\
\text { treatments as } \\
\text { risks for implant } \\
\text { therapy }\end{array}$ & $\begin{array}{l}18 \text { studies: } \\
\text { case } \\
\text { controlled } \\
\text { matched } \\
\text { chart } \\
\text { survey, } \\
\text { cohort and } \\
\text { case } \\
\text { series }\end{array}$ & $\begin{array}{l}\text { Patients with } \\
\text { and without } \\
\text { diabetes, type } \\
1 \text { or type } 2 \\
\text { and other risk } \\
\text { systemic and } \\
\text { local risk } \\
\text { factors also }\end{array}$ & $\begin{array}{l}\text { Dental implants failure: } \\
\text { no definition of this }\end{array}$ & $\begin{array}{l}\text { Dental implant failure rates in } \\
\text { systemic conditions including } \\
\text { diabetes } \\
\text { Covariates: } \\
\text { none presented }\end{array}$ & $\begin{array}{l}\text { 1. There was a large } \\
\text { heterogeneity in papers in a } \\
\text { review of one database } \\
\text { 2. There is unequivocal } \\
\text { evidence that patients with } \\
\text { diabetes have higher dental } \\
\text { implant failure rates. } \\
\text { 3. Diabetic patients tend to } \\
\text { have early failure }\end{array}$ & $\begin{array}{l}\text { 1. it is not possible to distinguish } \\
\text { between subtypes of systemic } \\
\text { diseases such as diabetes type } 1 \text { and } 2 \\
\text { or primary and secondary osteoporosis } \\
\text { 2.The supposition that subjects with } \\
\text { diabetes tend to have higher failure } \\
\text { rates is equivocal }\end{array}$ & $\begin{array}{l}\text { Low }^{3} \\
\text { Amstar criteria not } \\
\text { met: } \\
\text { no comprehensive } \\
\text { literature search, } \\
\text { no tables } \\
\text { included, no study } \\
\text { characteristics, no } \\
\text { synthesis, no } \\
\text { scientific quality } \\
\text { assessed }\end{array}$ \\
\hline $\begin{array}{l}\text { Carramollino- } \\
\text { cuellar et al. } \\
2014^{36} \\
\text { Relationship } \\
\text { between the oral } \\
\text { cavity and } \\
\text { cardiovascular } \\
\text { diseases and } \\
\text { metabolic } \\
\text { syndrome }\end{array}$ & $\begin{array}{l}40 \text { studies } \\
\text { - Type of } \\
\text { studies not } \\
\text { include. }\end{array}$ & $\begin{array}{l}\text { Diabetic or } \\
\text { CHS sufferers } \\
\text { with } \\
\text { periodontal } \\
\text { disease. }\end{array}$ & $\begin{array}{l}\text { Periodontal disease. No } \\
\text { definition. }\end{array}$ & $\begin{array}{l}\text { Bidirectional relationship of } \\
\text { metabolic syndrome } \\
\text { (including DM) and } \\
\text { periodontal disease } \\
\text { Covariates: } \\
\text { none presented }\end{array}$ & $\begin{array}{l}\text { 1. Evidence suggests that there } \\
\text { is a moderate association } \\
\text { between obesity, and } \\
\text { particularly diabetes mellitus, } \\
\text { could be related to an increased } \\
\text { susceptibility to periodontitis. } \\
\text { 2. However, it is not clear } \\
\text { whether periodontal treatment } \\
\text { could improve the systemic } \\
\text { conditions of such patients. }\end{array}$ & $\begin{array}{l}\text { The existing scientific evidence } \\
\text { suggests that obesity, and particularly } \\
\text { diabetes mellitus, could be related to } \\
\text { an increased susceptibility to } \\
\text { periodontitis. However, it is not clear } \\
\text { whether periodontal treatment could } \\
\text { improve the systemic conditions of } \\
\text { such patients }\end{array}$ & $\begin{array}{l}\text { High }^{8} \\
\text { Amstar criteria not } \\
\text { met: } \\
\text { No study } \\
\text { selection, no } \\
\text { process data } \\
\text { collection, no } \\
\text { synthesis }\end{array}$ \\
\hline $\begin{array}{l}\text { Chavarry et al. } \\
2009^{14}\end{array}$ & $\begin{array}{l}57 \text { papers: } \\
49 \text { cross } \\
\text { sectional } \\
\text { studies, }\end{array}$ & $\begin{array}{l}\text { Patients with } \\
\text { periodontal } \\
\text { disease and } \\
\text { diabetes (type }\end{array}$ & $\begin{array}{l}\text { Periodontal disease: } \\
\text { clinical measures (PPD } \\
\text { or CAL) radiographic }\end{array}$ & $\begin{array}{l}\text { Mean differences in PPD and } \\
\text { CAL }\end{array}$ & $\begin{array}{l}\text { 1. Random effect model } \\
\text { showed a significant } \\
\text { association with clinical } \\
\text { attachment level (mean }\end{array}$ & $\begin{array}{l}\text { 1. There is enough evidence to } \\
\text { consider type } 2 \text { DM as a risk factor for } \\
\text { destructive periodontal disease. }\end{array}$ & $\mathrm{High}^{8}$ \\
\hline
\end{tabular}




\begin{tabular}{|c|c|c|c|c|c|c|c|}
\hline $\begin{array}{l}\text { The relationship } \\
\text { between } \\
\text { diabetes mellitus } \\
\text { and destructive } \\
\text { periodontitis: a } \\
\text { meta-analysis }\end{array}$ & $\begin{array}{l}\text { others } \\
\text { longitudina } \\
\text { I studies }\end{array}$ & $\begin{array}{l}1 \text { and 2) and } \\
\text { people without } \\
\text { diabetes }\end{array}$ & $\begin{array}{l}\text { evidence of alveolar } \\
\text { bone loss }\end{array}$ & $\begin{array}{l}\text { Covariates: } \\
\text { none in selection criteria. } \\
\text { However variable covariates } \\
\text { for each paper presented } \\
\text { including age, gender, } \\
\text { duration of diabetes, HIV, } \\
\text { pregnancy, smoking, number } \\
\text { of teeth }\end{array}$ & $\begin{array}{l}\text { difference }=1.00[\mathrm{Cl} 95 \%= \\
0.15 \text { to } 1.84] \text { ) and periodontal } \\
\text { pocket depth (mean difference } \\
=0.46[\mathrm{Cl} 95 \%=0.01 \text { to } 0.91] \text { ) } \\
\text { between type } 2 \text { diabetics and } \\
\text { non-diabetics } \\
\text { 2. Type } 2 \text { diabetes mellitus can } \\
\text { be considered a risk factor for } \\
\text { periodontitis }\end{array}$ & $\begin{array}{l}\text { 2. More studies are needed to assess if } \\
\text { type } 1 \mathrm{DM} \text { is a true risk factor for } \\
\text { periodontal disease } \\
\text { 3. In future studies on type } 1 \mathrm{DM} \text { the } \\
\text { inclusion of population aged } 25 \text { years } \\
\text { and above is recommended }\end{array}$ & $\begin{array}{l}\text { Amstar criteria not } \\
\text { met: } \\
\text { no study selection } \\
\text { criteria, no } \\
\text { excluded table, no } \\
\text { synthesis no } \\
\text { conflict of interest }\end{array}$ \\
\hline $\begin{array}{l}\text { Smoking, } \\
\text { Radiotherapy, } \\
\text { Diabetes and } \\
\text { Osteoporosis as } \\
\text { Risk Factors for } \\
\text { Dental Implant } \\
\text { Failure: A Meta- } \\
\text { Analysis }\end{array}$ & $\begin{array}{l}58 \text { studies } \\
5 \text { in } \\
\text { relation to } \\
\text { diabetes. } \\
3 \\
\text { prospectiv } \\
\text { e and } 2 \\
\text { retrospecti } \\
\text { ve } \\
\text { observatio } \\
\text { nal studies }\end{array}$ & $\begin{array}{l}\text { Patients with } \\
\text { dental } \\
\text { implants who } \\
\text { had diabetes } \\
\text { and other } \\
\text { systemic } \\
\text { conditions }\end{array}$ & $\begin{array}{l}\text { Dental implant failure: } \\
\text { no definition given }\end{array}$ & $\begin{array}{l}\text { Comparison of Implant failure } \\
\text { rates in people with different } \\
\text { risk factors } \\
\text { Covariates: } \\
\text { none presented }\end{array}$ & $\begin{array}{l}\text { For diabetes: no inverse impact } \\
\text { of diabetes }(n=5 ; R R=0.90 ; \\
95 \% \mathrm{Cl}, 0.62-1.32) \text { on the risk } \\
\text { of dental implant failure was } \\
\text { found }\end{array}$ & $\begin{array}{l}\text { 1. Smoking and radiotherapy were } \\
\text { associated with an increased risk of } \\
\text { dental implant failure } \\
\text { 2. The relationship between diabetes } \\
\text { and osteoporosis and the risk of } \\
\text { implant failure warrant further study }\end{array}$ & $\begin{array}{l}\text { High }^{7} \\
\text { Amstar not met: } \\
\text { no priori design, } \\
\text { no characteristics, } \\
\text { no status in } \\
\text { selection, no table } \\
\text { of excluded } \\
\text { studies, no quality } \\
\text { assessment }\end{array}$ \\
\hline
\end{tabular}




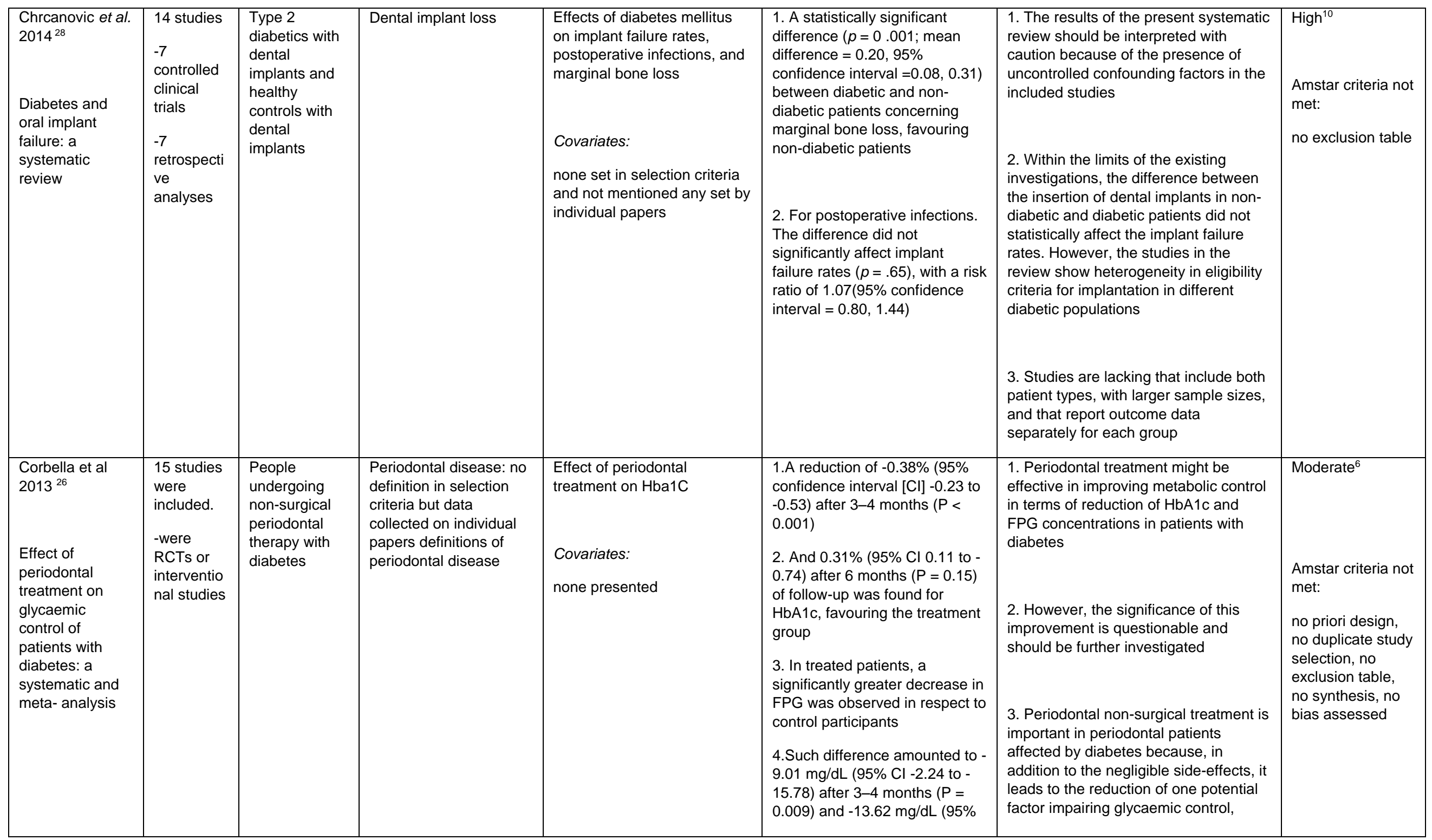




\begin{tabular}{|c|c|c|c|c|c|c|c|}
\hline & & & & & $\begin{array}{l}\mathrm{Cl} 0.45 \text { to }-27.69) \text { after } 6 \\
\text { months }(\mathrm{P}=0.06) \text { from } \\
\text { treatment, respectively } \\
\text { 5.In participants treated with } \\
\text { adjunctive antimicrobials, a } \\
\text { non-significant increase of } \\
\mathrm{HbA} 1 \mathrm{c} \text { was observed } 3 \text { months } \\
\text { after treatment, whereas FPG } \\
\text { decreased by } 0.27 \mathrm{mg} / \mathrm{dL}(95 \% \\
\mathrm{Cl} 39.56 \text { to }-40.11 ; \mathrm{P}=0.99)\end{array}$ & $\begin{array}{l}\text { while preserving dental and periodontal } \\
\text { health }\end{array}$ & \\
\hline $\begin{array}{l}\text { Darre et al. } 2008 \\
37 \\
\text { Efficacy of } \\
\text { periodontal } \\
\text { treatment on } \\
\text { glycaemic } \\
\text { control in } \\
\text { diabetes } \\
\text { mellitus: meta - } \\
\text { analysis of } \\
\text { interventional } \\
\text { studies }\end{array}$ & $\begin{array}{l}25 \text { studies } \\
9 \text { RCTs } \\
16 \text { non- } \\
\text { controlled } \\
\text { trials }\end{array}$ & $\begin{array}{l}\text { Diabetic } \\
\text { patients with } \\
\text { periodontal } \\
\text { disease } \\
\text { undergoing } \\
\text { and not } \\
\text { undergoing } \\
\text { periodontal } \\
\text { therapy }\end{array}$ & $\begin{array}{l}\text { Periodontitis: a common } \\
\text { chronic gram-negative } \\
\text { anaerobic infection of } \\
\text { the periodontium that } \\
\text { causes destruction of } \\
\text { periodontal tissues and } \\
\text { loss of alveolar bone } \\
\text { (CAL,BOP,PPD,PI,Gl) } \\
\text { Periodontal treatment: } \\
\text { Root planing scaling, } \\
\text { OHI and antimicrobial } \\
\text { therapy }\end{array}$ & $\begin{array}{l}\text { Effect of periodontal disease } \\
\text { and treatment on glycaemic } \\
\text { control } \\
\text { Covariates adjusted Noted } \\
\text { from individual papers, } \\
\text { although all did not account } \\
\text { for these. Covariates } \\
\text { adjusted by paper include } \\
\text { age, BMI, duration of } \\
\text { diabetes, and number of } \\
\text { teeth. Also looked at if } \\
\text { studies reported ethnicity, } \\
\text { gender, diabetic treatment, } \\
\text { type of diabetes and its } \\
\text { treatment and smoking }\end{array}$ & $\begin{array}{l}\text { The standardised mean } \\
\text { difference in } \mathrm{HbA} 1 \mathrm{c} \text { with the } \\
\text { treatment of periodontal } \\
\text { disease was } 0.46 \text { ( } 95 \% \mathrm{Cl} \text { : } \\
0.11,0.82) \text {. These findings } \\
\text { suggest that periodontal } \\
\text { treatment could lead to a } \\
\text { significant } 0.79 \% \text { ( } 95 \% \mathrm{Cl}: 0.19 \text {, } \\
1.40 \text { ) reduction in } \mathrm{HbA} 1 \mathrm{c} \text { level }\end{array}$ & $\begin{array}{l}\text { Periodontal treatment could improve } \\
\text { glycaemic control. These results need } \\
\text { to be viewed with caution because of a } \\
\text { lack of robustness, and deficiencies in } \\
\text { the design of some of the studies } \\
\text { included }\end{array}$ & $\begin{array}{l}\text { High }^{8} \\
\text { Amstar criteria not } \\
\text { met: } \\
\text { no priori design, } \\
\text { no exclusion } \\
\text { table, no } \\
\text { synthesis }\end{array}$ \\
\hline $\begin{array}{l}\text { Engbrettson and } \\
\text { Koecher } \\
2013^{18} \\
\text { Evidence that } \\
\text { periodontal } \\
\text { treatment } \\
\text { improves } \\
\text { diabetes } \\
\text { outcomes: a } \\
\text { Systematic }\end{array}$ & $\begin{array}{l}9 \mathrm{RCT} \\
\text { studies }\end{array}$ & $\begin{array}{l}\text { Individuals } \\
\text { with } \\
\text { periodontal } \\
\text { disease and } \\
\text { diabetes over } \\
\text { the age of } 18\end{array}$ & $\begin{array}{l}\text { Periodontal treatment: } \\
\text { periodontal therapy, } \\
\text { either surgical or non- } \\
\text { surgical, with or without } \\
\text { the use of adjunctive } \\
\text { antibiotics, antiseptics, } \\
\text { or oral hygiene } \\
\text { instruction }\end{array}$ & $\begin{array}{l}\text { The effect of periodontal } \\
\text { treatment on diabetes } \\
\text { outcomes } \\
\text { Covariates: } \\
\text { none presented }\end{array}$ & $\begin{array}{l}\text { 1. Mean treatment effect of } \\
-0.36 \% \mathrm{HbA} 1 \mathrm{c}(\mathrm{Cl}-0.54,- \\
0.19) \text { compared to no treatment } \\
\text { after periodontal therapy } \\
(\mathrm{p}<0.0001) \text {. } \\
\text { 2. Heterogeneity - low bias (i2) } \\
\text { 3. However, poor sample sizes } \\
\text { of included studies }\end{array}$ & $\begin{array}{l}\text { 1. The modest reduction in } \mathrm{HbA} 1 \mathrm{c} \\
\text { observed as a result of periodontal } \\
\text { therapy in subjects with type } 2 \text { diabetes } \\
\text { is consistent with previous systematic } \\
\text { reviews. } \\
\text { 2. Despite this finding, multi-centre } \\
\text { trials of sufficient sample size are } \\
\text { lacking }\end{array}$ & $\begin{array}{l}\text { Moderate }^{7} \\
\text { Amstar criteria not } \\
\text { met: } \\
\text { no duplicate study } \\
\text { selection, no } \\
\text { comprehensive } \\
\text { literature search, } \\
\text { no publication } \\
\text { status in selection, } \\
\text { no synthesis }\end{array}$ \\
\hline
\end{tabular}




\begin{tabular}{|c|c|c|c|c|c|c|c|}
\hline $\begin{array}{l}\text { Review and } \\
\text { Meta-analysis }\end{array}$ & & & & & & & \\
\hline $\begin{array}{l}\text { Morais de } \\
\text { Freitas } 2013^{33} \\
\text { Factors related } \\
\text { to dry mouth and } \\
\text { low salivary flow } \\
\text { rates in diabetic } \\
\text { elderly: a } \\
\text { systematic } \\
\text { literature review }\end{array}$ & $\begin{array}{l}5 \text { studies } \\
4 \text { cross } \\
\text { sectional } \\
1 \\
\text { longitudina } \\
\text { I }\end{array}$ & $\begin{array}{l}\text { Elderly with } \\
\text { diabetes with } \\
\text { or without a } \\
\text { sensation of } \\
\text { dry mouth }\end{array}$ & $\begin{array}{l}\text { Salivary dysfunction } \\
\text { xerostomia }\end{array}$ & $\begin{array}{l}\text { Factors related to xerostomia } \\
\text { and/or hypo-salivation in } \\
\text { elderly patients with diabetes } \\
\text { Covariates: } \\
\text { age, gender, patient health, } \\
\text { medications use, disease } \\
\text { stage, socioeconomic status, } \\
\text { presence of neuropathy }\end{array}$ & $\begin{array}{l}\text { Hypo-salivation in elderly } \\
\text { people with diabetes may occur } \\
\text { in terms of stimulated response } \\
\text { in those with poor glycaemic } \\
\text { control. eg due to drugs/ anxiety } \\
\text { etc more studies needed to } \\
\text { confirm this }\end{array}$ & $\begin{array}{l}\text { 1. Cannot draw definitive conclusions } \\
\text { about the factors that cause xerostomia } \\
\text { and/or hypo-salivation in elderly } \\
\text { patients with D.M. } \\
\text { 2. More longitudinal studies are needed }\end{array}$ & $\begin{array}{l}\text { Moderate }^{5} \\
\text { Amstar criteria not } \\
\text { met: } \\
\text { no priori design, } \\
\text { no duplicate } \\
\text { selection, no } \\
\text { publication status } \\
\text { in selection, no } \\
\text { excluded, no bias } \\
\text { assesses, no } \\
\text { conflict of interest }\end{array}$ \\
\hline $\begin{array}{l}\text { Gong et al. } \\
2015^{32} \\
\text { Type } 2 \text { diabetes } \\
\text { mellitus and risk } \\
\text { of oral cancer } \\
\text { and } \\
\text { precancerous } \\
\text { lesions: A meta- } \\
\text { analysis of } \\
\text { observational } \\
\text { studies }\end{array}$ & $\begin{array}{l}13 \text { studies } \\
\text { included: } \\
4 \text { case } \\
\text { control } \\
9 \text { cohort }\end{array}$ & $\begin{array}{l}\text { Patients with } \\
\text { type } 2 \\
\text { diabetes } \\
\text { mellitus }\end{array}$ & $\begin{array}{l}\text { Oral cancer and } \\
\text { precancerous lesions }\end{array}$ & $\begin{array}{l}\text { Associations between type } 2 \\
\text { diabetes mellitus (type } 2 \text { DM) } \\
\text { and risk of oral cancer and } \\
\text { precancerous } \\
\text { Lesions } \\
\text { Covariates: } \\
\text { covariates adjusted or by } \\
\text { matching, and the effect } \\
\text { estimates with } 95 \% \text { Cis were } \\
\text { only included in the study. } \\
\text { Though variations in which } \\
\text { were adjusted for between } \\
\text { studies. These included age, } \\
\text { gender, smoking, alcohol, } \\
\text { duration of chewing, BMl } \\
\text { physical activity, education, } \\
\text { diet, family history of cancer, } \\
\text { health status, marital status }\end{array}$ & $\begin{array}{l}\text { 1. Type } 2 \text { DM had a significantly } \\
\text { elevated incidence of oral } \\
\text { cancer (SRR }=1.15,95 \% \mathrm{Cl} \text { : } \\
\text { 1.02-1.29; Pheterogeneity }= \\
0.277, \mathrm{I} 2=15.4 \% ; 10 \text { studies) } \\
\text { 2. Type } 2 \mathrm{DM} \text { was associated } \\
\text { with increased oral cancer } \\
\text { mortality (SRR }=1.41,95 \% \mathrm{Cl} \text { : } \\
\text { 1.16-1.72; } 4 \text { studies) } \\
\text { 3. Positive association between } \\
\text { type } 2 \text { DM and risk of oral } \\
\text { precancerous lesions (SRR = } \\
\text { 1.85, } 95 \% \mathrm{Cl}: 1.23-2.80 ; \\
\text { Pheterogeneity = } 0.038, \mathrm{I} 2= \\
57.5 \% \\
\text { 4. No bias }\end{array}$ & $\begin{array}{l}\text { The findings of this meta-analysis } \\
\text { indicate that compared with non- } \\
\text { diabetic individuals, individuals with } \\
\text { type } 2 \text { DM have an elevated risk of oral } \\
\text { cancer and precancerous lesions } \\
\text { development }\end{array}$ & $\begin{array}{l}\text { All Amstar criteria } \\
\text { met }\end{array}$ \\
\hline $\begin{array}{l}\text { Ismail et al. } \\
2015^{27}\end{array}$ & 37 studies & $\begin{array}{l}\text { Children with } \\
\text { type } 1 \\
\text { diabetes }\end{array}$ & $\begin{array}{l}\text { Caries } \\
\text { DMFT }\end{array}$ & $\begin{array}{l}\text { Oral health status of children } \\
\text { with type } 1 \text { diabetes. }\end{array}$ & $\begin{array}{l}\text { 1. Conflicting evidence } \\
\text { regarding the caries experience } \\
\text { of children with type } 1 \text { diabetes }\end{array}$ & $\begin{array}{l}\text { 1. There is conflicting evidence } \\
\text { regarding the caries experience of } \\
\text { children with type } 1 \text { diabetes, but they } \\
\text { exhibit poorer periodontal health status }\end{array}$ & Moderate $^{6}$ \\
\hline
\end{tabular}




\begin{tabular}{|c|c|c|c|c|c|c|c|}
\hline $\begin{array}{l}\text { Oral health of } \\
\text { children with } \\
\text { type } 1 \text { diabetes } \\
\text { mellitus: A } \\
\text { systematic } \\
\text { review }\end{array}$ & $\begin{array}{l}7 \\
\text { longitudina } \\
\text { I } \\
\text { Rest case } \\
\text { controlled }\end{array}$ & & Periodontal health & $\begin{array}{l}\text { Covariates: } \\
\text { none presented }\end{array}$ & $\begin{array}{l}\text { 2. Exhibit poorer periodontal } \\
\text { health status } \\
\text { 3. Greater plaque accumulation } \\
\text { 4. Further studies are warranted }\end{array}$ & $\begin{array}{l}\text { with greater plaque accumulation } \\
\text { compared to healthy children } \\
\text { 2. Further studies are warranted to } \\
\text { assess the oral health status of } \\
\text { children with type } 1 \text { diabetes. }\end{array}$ & $\begin{array}{l}\text { Amstar criteria not } \\
\text { met: } \\
\text { No publication } \\
\text { status in selection, } \\
\text { no exclusion } \\
\text { table, no quality } \\
\text { assessed, no } \\
\text { synthesis, no bias } \\
\text { assessed }\end{array}$ \\
\hline $\begin{array}{l}\text { Does periodontal } \\
\text { treatment } \\
\text { improve } \\
\text { glycaemic } \\
\text { control in } \\
\text { diabetic } \\
\text { patients? A } \\
\text { Meta-analysis of } \\
\text { Intervention } \\
\text { Studies }\end{array}$ & $\begin{array}{l}10 \text { studies } \\
\text { all } \\
\text { interventio } \\
\text { nal }\end{array}$ & $\begin{array}{l}\text { Type } 2 \\
\text { Diabetics } \\
\text { patients } \\
\text { undergoing } \\
\text { periodontal } \\
\text { treatment }\end{array}$ & $\begin{array}{l}\text { Periodontal treatment. } \\
\text { No definition }\end{array}$ & $\begin{array}{l}\text { Periodontal treatment effect } \\
\text { on Hba1C } \\
\text { Covariates: } \\
\text { none presented }\end{array}$ & $\begin{array}{l}\text { 1. A non-significant } 0.38 \% \\
\text { reduction in actual value of } \\
\text { HbA1c, and } 0.71 \% \text { among } 5 \\
\text { studies conducted among } \\
\text { patients with type } 2 \text { diabetes } \\
\text { 2. A non-significant } 0.38 \% \\
\text { reduction in actual value of } \\
\text { HbA1c, and } 0.71 \% \text { among } 5 \\
\text { studies conducted among } \\
\text { patients with type } 2 \text { diabetes } \\
\text { 3. Further studies with a larger } \\
\text { sample size are needed (246) }\end{array}$ & $\begin{array}{l}\text { 1. Future research needed } \\
\text { 2. Smoking, BMI, and diet, as well as } \\
\text { baseline characteristics affecting } \\
\text { glycaemic control - should be adjusted } \\
\text { fo } \\
\text { 3. Participants should be limited to type } \\
2 \text { diabetic patients on oral } \\
\text { hypoglycaemic agents or diet regimen } \\
\text { only, etc }\end{array}$ & $\begin{array}{l}\text { Amstar criteria not } \\
\text { met: } \\
\text { no priori, no status } \\
\text { of publications in } \\
\text { selection, no } \\
\text { synthesis, no } \\
\text { conflict of interest }\end{array}$ \\
\hline $\begin{array}{l}\text { Javed and } \\
\text { Ramanos } 2009^{29} \\
\text { Impact of } \\
\text { Diabetes Mellitus } \\
\text { and Glycaemic } \\
\text { Control on the } \\
\text { Osseo- } \\
\text { integration of } \\
\text { Dental Implants: } \\
\text { A Systematic } \\
\text { Literature } \\
\text { Review }\end{array}$ & $\begin{array}{l}18 \text { studies: } \\
10 \text { clinical } \\
8 \text { experi- } \\
\text { mental }\end{array}$ & $\begin{array}{l}\text { Humans with } \\
\text { diabetes with } \\
\text { dental } \\
\text { implants }\end{array}$ & $\begin{array}{l}\text { conventional dental } \\
\text { implants and/or } \\
\text { immediate loading of } \\
\text { dental implants }\end{array}$ & $\begin{array}{l}\text { Can patients with diabetes be } \\
\text { good candidates for dental } \\
\text { implant therapy? And how } \\
\text { does hyperglycaemia and } \\
\text { glycaemic control influence } \\
\text { osseo-integration? }\end{array}$ & $\begin{array}{l}\text { 1. Poorly controlled diabetes } \\
\text { negatively affects implant } \\
\text { osseo-integration; however, } \\
\text { under optimal serum glycaemic } \\
\text { control, osseo-integration can } \\
\text { successfully occur in patients } \\
\text { with diabetes } \\
\text { 2. Use of antiseptic mouth } \\
\text { rinses and oral-hygiene } \\
\text { maintenance helps in achieving } \\
\text { a successful dental implant } \\
\text { osseo-integration in subjects } \\
\text { with diabetes } \\
\text { 3. A successful dental implant } \\
\text { osseo-integration can be } \\
\text { accomplished in subjects with } \\
\text { diabetes with good metabolic }\end{array}$ & $\begin{array}{l}\text { A successful dental implant osseo- } \\
\text { integration can be accomplished in } \\
\text { subjects with diabetes with good } \\
\text { metabolic control (serum glycaemic } \\
\text { level and haemoglobin A1c in normal } \\
\text { range) in a similar manner as in } \\
\text { subjects without diabetes }\end{array}$ & $\begin{array}{l}\text { Moderate }^{5} \\
\text { Amstar criteria not } \\
\text { met: } \\
\text { no excluded table, } \\
\text { no characteristics, } \\
\text { no quality } \\
\text { assessment, no } \\
\text { synthesis, no bias } \\
\text { assessed }\end{array}$ \\
\hline
\end{tabular}




\begin{tabular}{|c|c|c|c|c|c|c|c|}
\hline & & & & & $\begin{array}{l}\text { control (serum glycaemic level } \\
\text { and haemoglobin A1c in normal } \\
\text { range) in a similar manner as in } \\
\text { subjects without diabetes } \\
\text { 4. Dental implant therapy in } \\
\text { diabetics without good } \\
\text { glycaemic control remains } \\
\text { contraindicated }\end{array}$ & & \\
\hline $\begin{array}{l}\text { Khader et al. } \\
2005^{15} \\
\text { Periodontal } \\
\text { status of } \\
\text { diabetics } \\
\text { compared with } \\
\text { non- diabetics: a } \\
\text { meta-analysis }\end{array}$ & $\begin{array}{l}23 \text { studies } \\
18 \\
\text { comparativ } \\
\text { e cross } \\
\text { sectional, } \\
\text { 3prospecti } \\
\text { ve cohort } \\
\text { and } 2 \text { trials }\end{array}$ & $\begin{array}{l}\text { Diabetics and } \\
\text { non- diabetics } \\
\text { with } \\
\text { periodontitis }\end{array}$ & $\begin{array}{l}\text { Periodontal status. } \\
\text { PI,GI, PPD, CAL }\end{array}$ & $\begin{array}{l}\text { Oral hygiene and periodontal } \\
\text { disease } \\
\text { Covariates: } \\
\text { none presented }\end{array}$ & $\begin{array}{l}\text { 1. The severity of oral hygiene } \\
\text { and POD was worse in } \\
\text { diabetics. } \\
\text { 2. The extent of POD was } \\
\text { similar in diabetics and non- } \\
\text { diabetics } \\
\text { 3. Heterogeneity a problem }\end{array}$ & $\begin{array}{l}\text { Diabetics had a significantly higher } \\
\text { severity but the same extent of } \\
\text { periodontal disease than non-diabetics }\end{array}$ & $\begin{array}{l}\text { Moderate }^{6} \\
\text { Amstar criteria not } \\
\text { met: } \\
\text { no comprehensive } \\
\text { literature search, } \\
\text { no table of } \\
\text { excluded studies, } \\
\text { no quality } \\
\text { assessed, no } \\
\text { conflict of interest }\end{array}$ \\
\hline $\begin{array}{l}\text { Kudiyirickal } \\
2014^{39} \\
\text { Diabetes mellitus } \\
\text { and oral health }\end{array}$ & 78 studies & $\begin{array}{l}\text { People with } \\
\text { diabetes }\end{array}$ & $\begin{array}{l}\text { Periodontal disease, } \\
\text { pulp, dry mouth, root } \\
\text { caries, wound healing } \\
\text { Oral candidiasis } \\
\text { No definitions }\end{array}$ & Oral health status & $\begin{array}{l}\text { Diabetes can worsen oral } \\
\text { infections and vice versa. In the } \\
\text { literature, periodontitis and } \\
\text { diabetes in the young to middle- } \\
\text { aged adults have been the most } \\
\text { widely researched area }\end{array}$ & $\begin{array}{l}\text { Several studies have shown the inter- } \\
\text { link between oral health diabetes, } \\
\text { thereby highlighting the importance of } \\
\text { proper management of orofacial } \\
\text { infections in the reduction of the } \\
\text { disease-related morbidity from diabetes } \\
\text { and vice versa }\end{array}$ & $\begin{array}{l}\text { Moderate }^{4} \\
\text { Amstar criteria not } \\
\text { met: } \\
\text { no priori, no } \\
\text { characteristics, no } \\
\text { duplicate selection } \\
\text { no publication } \\
\text { status in selection, } \\
\text { no quality } \\
\text { assessed }\end{array}$ \\
\hline $\begin{array}{l}\text { Effect of non- } \\
\text { surgical } \\
\text { periodontal }\end{array}$ & 9 RCTs & $\begin{array}{l}\text { Type } 2 \\
\text { diabetics with } \\
\text { periodontal } \\
\text { disease }\end{array}$ & $\begin{array}{l}\text { Periodontal therapy: } \\
\text { none defined by } \\
\text { reviewers. SRP, SRP + } \\
\text { mouthwash variably in } \\
\text { individual studies }\end{array}$ & $\begin{array}{l}\text { Whether non-surgical } \\
\text { periodontal treatment can } \\
\text { reduce the Haemoglobin A1c } \\
\text { (HbA1c) \% level in type } 2 \\
\text { diabetic patients }\end{array}$ & $\begin{array}{l}\text { Pooled analysis }(\mathrm{n}=1082) \\
\text { showed }-0.27 \%(95 \% \mathrm{Cl}:-0.46 \\
\% \text { to }-0.07 \%, \mathrm{p}=0.007) \\
\text { absolute difference in HbA1c } \% \\
\text { with treatment while studies } \\
\text { with sufficient sample size had } \\
\text { HbA1c } \% \text { change of }-0.014 \%\end{array}$ & $\begin{array}{l}\text { The moderate reduction in HbA1c after } \\
\text { the non-surgical therapy in patients } \\
\text { with type } 2 \text { diabetes is consistent with } \\
\text { previous systematic reviews. However, } \\
\text { more large scale and high-quality }\end{array}$ & $\begin{array}{l}\text { Amstar criteria not } \\
\text { met: }\end{array}$ \\
\hline
\end{tabular}




\begin{tabular}{|c|c|c|c|c|c|c|c|}
\hline $\begin{array}{l}\text { treatment on } \\
\text { glycaemic } \\
\text { control of } \\
\text { patients with } \\
\text { diabetes: a } \\
\text { meta- analysis of } \\
\text { RCTs }\end{array}$ & & & & $\begin{array}{l}\text { Covariates: } \\
\text { none presented }\end{array}$ & $\begin{array}{l}\text { (95\% Cl:- } 0.18 \% \text { to } 0.16 \%, p= \\
0.87)\end{array}$ & $\begin{array}{l}\text { RCTs are necessitated to confirm } \\
\text { these results }\end{array}$ & $\begin{array}{l}\text { no priori design, } \\
\text { no duplicate } \\
\text { selection, no } \\
\text { public status } \\
\text { selection, no } \\
\text { quality assessed, } \\
\text { no conflict of } \\
\text { interest }\end{array}$ \\
\hline $\begin{array}{l}\text { Masceranhas } \\
2014^{34} \\
\text { Effect of } \\
\text { Diabetes Mellitus } \\
\text { Type } 2 \text { on } \\
\text { Salivary Glucose } \\
\text { - a systematic } \\
\text { review and } \\
\text { meta-analysis of } \\
\text { observational } \\
\text { studies }\end{array}$ & $\begin{array}{l}10 \\
\text { observatio } \\
\text { nal studies }\end{array}$ & $\begin{array}{l}\text { Type } 2 \\
\text { Diabetic } \\
\text { patients }\end{array}$ & Saliva glucose content & $\begin{array}{l}\text { The effectiveness of salivary } \\
\text { glucose to estimate } \\
\text { glycaemia and HbA1c. } \\
\text { Covariates: } \\
\text { none presented }\end{array}$ & $\begin{array}{l}\text { 1. Type } 2 \text { DM leads to a } \\
\text { consistent increase in salivary } \\
\text { glucose that remains detectable } \\
\text { in spite of food contamination, } \\
\text { variations in salivary flow rate or } \\
\text { presence of local autonomic } \\
\text { neuropathy. } \\
\text { 2.Our review also reports a } \\
\text { significant overall relationship } \\
\text { between salivary glucose } \\
\text { concentration and associated } \\
\text { glycaemia/HbA1c values, with } \\
\text { the correlation strength } \\
\text { increasing as we move to } \\
\text { higher glycaemia/HbA1c values } \\
\text { 3. Will allow a less painful and } \\
\text { invasive method for type } 2 \text { DM } \\
\text { screening or diabetic glucose } \\
\text { monitoring }\end{array}$ & $\begin{array}{l}\text { Significant overall relationship between } \\
\text { salivary glucose concentration } \\
\text { and associated glycaemia/HbA1c } \\
\text { values, with the correlation strength } \\
\text { increasing as we move to higher } \\
\text { glycaemia/HbA1c values }\end{array}$ & $\begin{array}{l}\text { Moderate }^{6} \\
\text { Amstar criteria not } \\
\text { met: } \\
\text { no duplicate } \\
\text { selection, no } \\
\text { status of } \\
\text { publication in } \\
\text { selection, no } \\
\text { excluded table, no } \\
\text { bias assessment, } \\
\text { no conflict of } \\
\text { interest }\end{array}$ \\
\hline $\begin{array}{l}\text { Systemic } \\
\text { diseases } \\
\text { affecting osseo- } \\
\text { integration } \\
\text { therapy }\end{array}$ & $\begin{array}{l}\text { 15: studies } \\
\text { eight case } \\
\text { series six } \\
\text { cross- } \\
\text { sectional, } \\
\text { longitudina } \\
\text { I or } \\
\text { retrospecti } \\
\text { ve one } \\
\text { matched } \\
\text { control } \\
\text { retrospecti } \\
\text { ve chart } \\
\text { survey }\end{array}$ & $\begin{array}{l}\text { Patients with } \\
\text { dental implant } \\
\text { with systemic } \\
\text { conditions and } \\
\text { including } \\
\text { diabetes }\end{array}$ & $\begin{array}{l}\text { Dental implants. None } \\
\text { described }\end{array}$ & $\begin{array}{l}\text { Impact of systemic diseases } \\
\text { and their treatment on the } \\
\text { success } \\
\text { of osseo-integration therapy } \\
\text { Covariates adjusted none } \\
\text { presented }\end{array}$ & $\begin{array}{l}\text { 1. No unequivocal tendency for } \\
\text { subjects with diabetes to have } \\
\text { higher failure rates emerged } \\
\text { 2. A significant increase in the } \\
\text { relative risk of implant failure } \\
\text { with diabetes }\end{array}$ & $\begin{array}{l}\text { The tendency for subjects with } \\
\text { diabetes to have higher failure rates is } \\
\text { equivocal }\end{array}$ & $\begin{array}{l}\text { Low }^{3} \\
\text { Amstar criteria not } \\
\text { met: } \\
\text { no comprehensive } \\
\text { literature search, } \\
\text { no status } \\
\text { publication in } \\
\text { selection, no } \\
\text { excluded table, no } \\
\text { quality assessed, } \\
\text { no synthesis, no }\end{array}$ \\
\hline
\end{tabular}




\begin{tabular}{|c|c|c|c|c|c|c|c|}
\hline & & & & & & & $\begin{array}{l}\text { bias assesses, no } \\
\text { conflict of interest }\end{array}$ \\
\hline $\begin{array}{l}\text { Oates et al. } \\
2013^{10} \\
\text { A critical review } \\
\text { of diabetes, } \\
\text { glycaemic } \\
\text { control, and } \\
\text { dental implant } \\
\text { therapy }\end{array}$ & 16 papers & $\begin{array}{l}\text { Patients with } \\
\text { diabetes and } \\
\text { dental } \\
\text { implants }\end{array}$ & Dental implants & $\begin{array}{l}\text { Implant therapy relative to } \\
\text { glycaemic control for patients } \\
\text { with diabetes } \\
\text { Covariates adjusted none } \\
\text { presented }\end{array}$ & $\begin{array}{l}\text { 1. Reported implant failures } \\
\text { rates for diabetic patients } \\
\text { ranged from } 0-14.3 \% \\
\text { 2. Identification and reporting of } \\
\text { glycaemic control was } \\
\text { insufficient or lacking in } 13 \text { of } \\
\text { the } 16 \text { studies } \\
\text { 3. Failed to demonstrate a } \\
\text { significant relationship between } \\
\text { glycaemic control and implant } \\
\text { failure, with failure rates ranging } \\
\text { from } 0-2.9 \%\end{array}$ & $\begin{array}{l}\text { Clinical evidence is lacking for the } \\
\text { association of glycaemic control with } \\
\text { implant failure while support is } \\
\text { emerging for implant therapy in } \\
\text { diabetes patients with appropriate } \\
\text { accommodations for delays in implant } \\
\text { integration based on glycaemic control }\end{array}$ & $\begin{array}{l}\text { Low }^{3} \\
\text { Amstar criteria not } \\
\text { met: } \\
\text { No priori design, } \\
\text { no excluded table, } \\
\text { no characteristics, } \\
\text { no comprehensive } \\
\text { literature search, } \\
\text { no quality } \\
\text { assessed, no } \\
\text { synthesis, no bias } \\
\text { assessed }\end{array}$ \\
\hline $\begin{array}{l}\text { Effect of } \\
\text { nonsurgical } \\
\text { periodontal } \\
\text { treatment on } \\
\text { glycosylated } \\
\text { haemoglobin in } \\
\text { diabetic patients: } \\
\text { a systematic } \\
\text { review - }\end{array}$ & $\begin{array}{l}\text { 21: } \\
13 \mathrm{RCT} \\
\text { And } 8 \text { non } \\
\text { RCT }\end{array}$ & $\begin{array}{l}\text { Type 1 } \\
\text { diabetics } \\
\text { undergoing } \\
\text { periodontal } \\
\text { therapy }\end{array}$ & $\begin{array}{l}\text { Periodontitis: none } \\
\text { specified by authors. } \\
\text { Collected definitions } \\
\text { based on CAL, PPD, } \\
\text { BOP, PI and number of } \\
\text { remaining teeth }\end{array}$ & $\begin{array}{l}\text { Effect of non-surgical } \\
\text { periodontal therapy in } \\
\text { reducing hba1c in type } 1 \\
\text { diabetics }\end{array}$ & $\begin{array}{l}\text { 1. A significant decrease in } \\
\text { HbA1c }(p<0.05) \text { was found in } \\
\text { only } 14(66 \%) \text { of the studies: } \\
69 \% \text { of the RCTs articles and } \\
62 \% \text { of the non-RCT articles } \\
\text { 2. After } 3-4 \text { or } 6 / 12 \text { follow up } \\
66.7 \% \text { of the studies, a } \\
\text { significant decrease in HbA1c } \\
\text { after periodontal treatment was } \\
\text { reported } \\
\text { 3. Only five of the } 21 \text { studies } \\
\text { (23.8\%) were of high } \\
\text { methodological quality and } \\
\text { reported significant } \\
\text { improvements in the metabolic } \\
\text { control of DM types } 1 \text { and } 2\end{array}$ & $\begin{array}{l}\text { Published literature is insufficient and } \\
\text { inconclusive to clearly support } \\
\text { periodontal treatment as a means to } \\
\text { improve serum HbA1c levels in } \\
\text { patients with type } 1 \mathrm{DM}\end{array}$ & $\begin{array}{l}\text { Moderate }^{7} \\
\text { Amstar criteria not } \\
\text { met: } \\
\text { no publication } \\
\text { status in selection, } \\
\text { no quality used } \\
\text { conclusions, no } \\
\text { synthesis, no } \\
\text { assessment of } \\
\text { bias }\end{array}$ \\
\hline $\begin{array}{l}\text { Renvert et al. } \\
2008^{40}\end{array}$ & 24 papers & $\begin{array}{l}\text { Patients with } \\
\text { peri-implant } \\
\text { disease }\end{array}$ & $\begin{array}{l}\text { Dental peri-implant } \\
\text { mucositis } \\
\text { perimplantitis }\end{array}$ & $\begin{array}{l}\text { Peri-implantitis risk factors } \\
\text { and methods of treating } \\
\text { these }\end{array}$ & $\begin{array}{l}\text { Potential risk indicators for peri- } \\
\text { implant disease including poor } \\
\text { oral hygiene, smoking, history } \\
\text { of periodontitis, diabetes, } \\
\text { genetic traits, alcohol }\end{array}$ & $\begin{array}{l}\text { Strong evidence that poor oral hygiene, } \\
\text { a history of periodontitis and cigarette } \\
\text { smoking, are risk indicators for peri- } \\
\text { implant disease }\end{array}$ & $\mathrm{High}^{8}$ \\
\hline
\end{tabular}




\begin{tabular}{|c|c|c|c|c|c|c|c|}
\hline $\begin{array}{l}\text { Non-surgical } \\
\text { treatment of peri- } \\
\text { implant } \\
\text { mucositis and } \\
\text { peri-implantitis: a } \\
\text { literature review } \\
\text { - }\end{array}$ & & & & $\begin{array}{l}\text { Covariates adjusted none } \\
\text { presented }\end{array}$ & $\begin{array}{l}\text { consumption and implant } \\
\text { surface }\end{array}$ & & $\begin{array}{l}\text { Amstar criteria not } \\
\text { met: } \\
\text { no comprehensive } \\
\text { search strategy, } \\
\text { no bias assessed, } \\
\text { no synthesis }\end{array}$ \\
\hline $\begin{array}{l}\text { Sgolgostra et al. } \\
2012^{20} \\
\text { Effectiveness of } \\
\text { Periodontal } \\
\text { Treatment to } \\
\text { Improve } \\
\text { Metabolic } \\
\text { Control in } \\
\text { Patients With } \\
\text { Chronic } \\
\text { Periodontitis and } \\
\text { Type } 2 \text { Diabetes: } \\
\text { A Meta-Analysis } \\
\text { of Randomized } \\
\text { Clinical Trials }\end{array}$ & 5 RCTs & $\begin{array}{l}\text { Patients with } \\
\text { type } 2 \\
\text { diabetes and } \\
\text { chronic } \\
\text { periodontitis } \\
\text { undergoing } \\
\text { scaling and } \\
\text { root planing }\end{array}$ & $\begin{array}{l}\text { Chronic periodontitis: a } \\
\text { complex disease that } \\
\text { develops from intra-oral } \\
\text { biofilms harbouring } \\
\text { periodontal pathogenic } \\
\text { micro-organisms. - } \\
\text { Individual studies } \\
\text { varied- some American } \\
\text { European consensus } \\
\text { criteria }\end{array}$ & $\begin{array}{l}\text { Effectiveness of SRP in } \\
\text { improving glycaemic and } \\
\text { metabolic control in patients } \\
\text { with CP and DM2 } \\
\text { Covariates adjusted n/a }\end{array}$ & $\begin{array}{l}\text { SRP was effective in the } \\
\text { reduction of } \mathrm{HbA} 1 \mathrm{C}(\mathrm{MD}=0.65 ; \\
95 \% \mathrm{Cl} 0.43 \text { to } 0.88 ; \mathrm{P}<0.05) \\
\text { and } \mathrm{FPG}(\mathrm{MD}=9.04 ; 95 \% \mathrm{Cl} \\
2.17 \text { to } 15.9 ; \mathrm{P}<0.05), \text { but no } \\
\text { significant differences were } \\
\text { found in the reduction of } \mathrm{TC} \text {, } \\
\mathrm{TG}, \mathrm{HDL} \text {, or } \mathrm{LDL}\end{array}$ & $\begin{array}{l}\text { Supports the effectiveness of SRP in } \\
\text { the improvement of glycaemic control } \\
\text { in patients with CP and DM2; however, } \\
\text { future studies are needed to confirm } \\
\text { these results }\end{array}$ & $\begin{array}{l}\text { High }^{9} \\
\text { Amstar criteria not } \\
\text { met: } \\
\text { no priori design no } \\
\text { scientific quality in } \\
\text { used in conclusion }\end{array}$ \\
\hline $\begin{array}{l}\text { Treatment of } \\
\text { periodontal } \\
\text { disease for } \\
\text { glycaemic } \\
\text { control in people } \\
\text { with diabetes }\end{array}$ & $\begin{array}{l}35 \text { Parallel } \\
\text { RCT } \\
\text { studies } \\
\text { (33 = } \\
\text { T2DM } \\
\text { only) }\end{array}$ & $\begin{array}{l}\text { Patients with } \\
\text { diabetes, } \\
\text { periodontitis } \\
\text { undergoing } \\
\text { scaling and } \\
\text { root planning } \\
\text { above age } 16\end{array}$ & $\begin{array}{l}\text { Periodontal disease is } \\
\text { the inflammation and } \\
\text { destruction of the } \\
\text { underlying supporting } \\
\text { tissues of the teeth }\end{array}$ & $\begin{array}{l}\text { Periodontal therapy (SRP +/- } \\
\text { adjunctives - surgery, } \\
\text { antimicrobials, other med) on } \\
\text { glycaemic control in people } \\
\text { with diabetes mellitus } \\
\text { Covariates adjusted n/a }\end{array}$ & $\begin{array}{l}\text { 1. Reported majority as being at } \\
\text { high risk of bias ( } 83 \%) \text {, two } \\
\text { studies }(6 \%) \text { as being at low } \\
\text { risk of bias, and four studies } \\
(11 \%) \text { as unclear } \\
\text { 2. Comparison } 1 \text { : low quality } \\
\text { evidence from } 14 \text { studies ( } 1,499 \\
\text { participants) comparing } \\
\text { periodontal therapy with no } \\
\text { active intervention/ usual care } \\
\text { demonstrated that mean } \mathrm{HbA} 1 \mathrm{c} \\
\text { was } 0.29 \% \text { lower }(95 \% \\
\text { confidence interval }(\mathrm{Cl}) 0.48 \%\end{array}$ & $\begin{array}{l}\text { Statistically significant improvements } \\
\text { were shown for all periodontal indices } \\
\text { (BOP, CAL, GI, PI and PPD) at } 3-4 \text { and } \\
6 \text { months in comparison } 1 \text {; however, } \\
\text { this was less clear for individual } \\
\text { comparisons within the broad category } \\
\text { of comparison } 2\end{array}$ & $\operatorname{High}^{11}$ \\
\hline
\end{tabular}




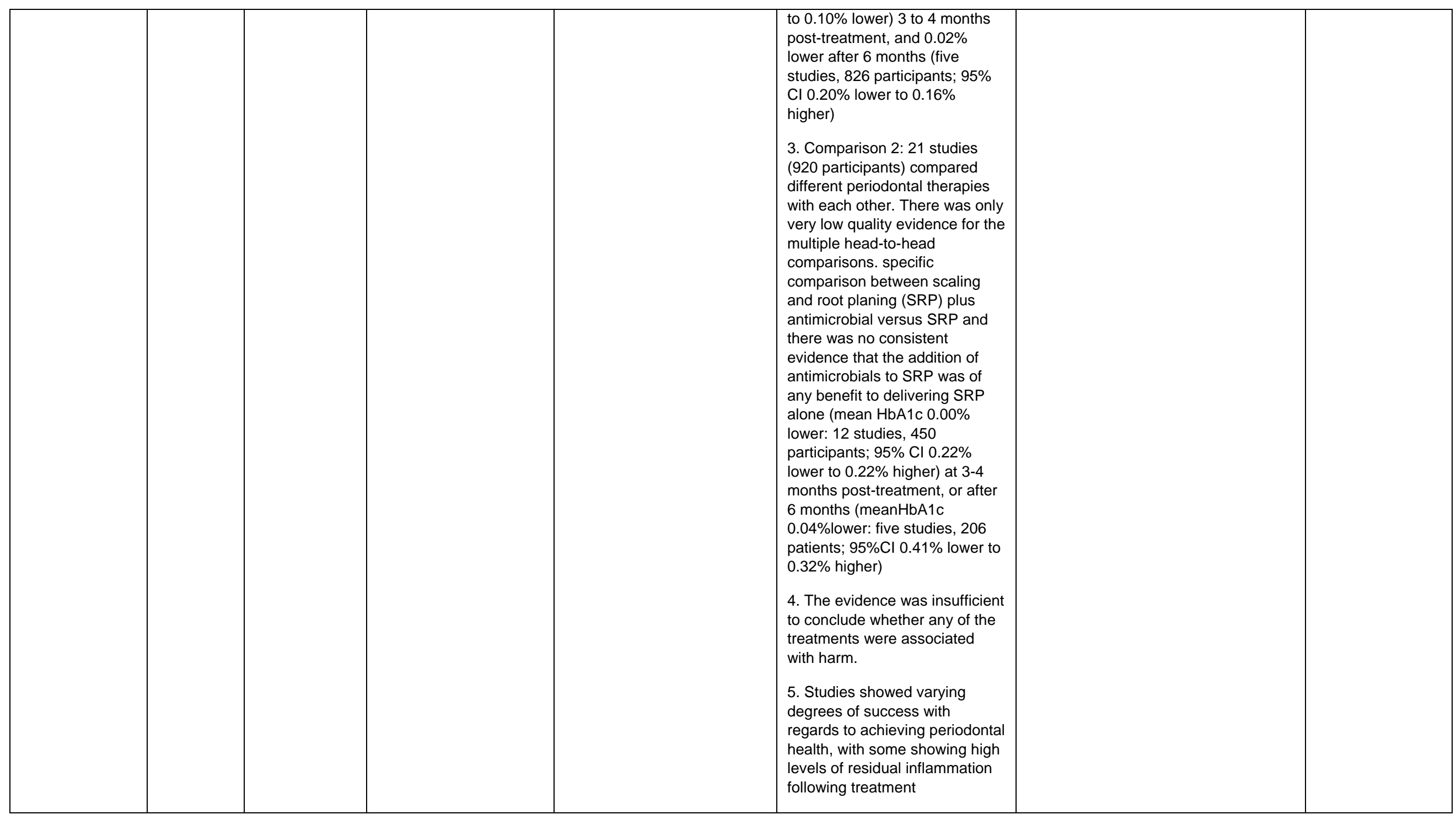




\begin{tabular}{|c|c|c|c|c|c|c|c|}
\hline $\begin{array}{l}\text { Sun et al. } 2014^{23} \\
\text { Effects of } \\
\text { periodontal } \\
\text { treatment on } \\
\text { glycaemic } \\
\text { control in type } 2 \\
\text { diabetes mellitus } \\
\text { patients: a meta- } \\
\text { analysis of RCTs }\end{array}$ & $\begin{array}{l}8 \text { RCT } \\
\text { studies } \\
\text { involving } \\
515 \\
\text { participant } \\
\text { s }\end{array}$ & $\begin{array}{l}\text { Type } 2 \\
\text { diabetics } \\
\text { having } \\
\text { periodontal } \\
\text { therapy }\end{array}$ & $\begin{array}{l}\text { Periodontal disease: no } \\
\text { specific definitions } \\
\text { presented }\end{array}$ & $\begin{array}{l}\text { Periodontal treatment } \\
\text { (SRP,OHI, +/-antimicrobials) } \\
\text { on glycaemic control in } \mathrm{t} 2 \mathrm{dm} \\
\text { patients } \\
\text { Covariates adjusted none } \\
\text { presented }\end{array}$ & $\begin{array}{l}\text { 1. } 1.03 \% \text { ( } 95 \% \text { confidence } \\
\text { interval: } 0.31 \% \text { to } 1.70 \%, P= \\
0.003 \text { ) from baseline to } 3 \\
\text { months, and } 1.18 \% \text { ( } 95 \% \\
\text { confidence interval: } 0.72 \% \text { to } \\
1.64 \%, P<0.001 \text { ) from baseline } \\
\text { to } 6 \text { months } \\
\text { 2. Indicated that periodontal } \\
\text { treatment could improve } \\
\text { glycaemic control in type } 2 \\
\text { diabetic patients with } \\
\text { periodontal diseases }\end{array}$ & $\begin{array}{l}\text { Our analysis indicated that periodontal } \\
\text { treatment could improve glycaemic } \\
\text { control in type } 2 \text { diabetic patients with } \\
\text { periodontal diseases }\end{array}$ & $\begin{array}{l}\text { Moderate }^{5} \\
\text { Amstar not met: } \\
\text { No priori design, } \\
\text { no excluded table, } \\
\text { no publication } \\
\text { status in selection, } \\
\text { no quality used in } \\
\text { conclusion, no } \\
\text { bias assessed, no } \\
\text { conflict of interest }\end{array}$ \\
\hline $\begin{array}{l}\text { Teew et al. } 2010 \\
21 \\
\text { The effect of } \\
\text { periodontal } \\
\text { treatment on } \\
\text { glycaemic } \\
\text { control of DM } \\
\text { pts: a systematic } \\
\text { review and } \\
\text { meta-analysis - }\end{array}$ & $\begin{array}{l}5 \\
\text { controlled } \\
\text { trial } \\
\text { studies }\end{array}$ & $\begin{array}{l}\text { Diabetic } \\
\text { patients } \\
\text { undergoing } \\
\text { periodontal } \\
\text { treatment }\end{array}$ & $\begin{array}{l}\text { Periodontitis: a chronic } \\
\text { multifactorial infectious } \\
\text { disease of the sup- } \\
\text { porting tissues of the } \\
\text { teeth } \\
\text {-Individual studies had } \\
\text { variable definitions of } \\
\text { periodontitis presented }\end{array}$ & $\begin{array}{l}\text { Periodontal therapy ( SRP } \\
+\mathrm{OHI}+/ \text { - adjunctive } \\
\text { Covariates adjusted none } \\
\text { presented }\end{array}$ & $\begin{array}{l}\text { 1. Favouring periodontal } \\
\text { intervention in type } 2 \text { diabetic } \\
\text { patients. Nevertheless, this } \\
\text { improvement in \%HbA1C must } \\
\text { be interpreted with care due to } \\
\text { limited robustness as evidenced } \\
\text { by heterogeneity } \\
\text { among studies } \\
\text { 2. Periodontal treatment leads } \\
\text { to an improvement of glycaemic } \\
\text { control in type } 2 \text { diabetic } \\
\text { patients for at least } 3 \text { months }\end{array}$ & $\begin{array}{l}\text { Suggest that periodontal treatment } \\
\text { leads to an improvement of glycaemic } \\
\text { control in type } 2 \text { diabetic patients for at } \\
\text { least } 3 \text { months }\end{array}$ & $\begin{array}{l}\text { Moderate }^{5} \\
\text { Amstar not met: } \\
\text { No duplicate study } \\
\text { selection, no } \\
\text { quality assessed, } \\
\text { no exclusion } \\
\text { table, no bias } \\
\text { assessed no } \\
\text { quality based } \\
\text { conclusion }\end{array}$ \\
\hline $\begin{array}{l}\text { Effects of } \\
\text { Periodontal } \\
\text { Therapy on } \\
\text { Metabolic } \\
\text { Control in } \\
\text { Patients With } \\
\text { Type } 2 \text { Diabetes }\end{array}$ & $\begin{array}{l}10 \text { trials of } \\
1,135 \\
\text { patients }\end{array}$ & $\begin{array}{l}\text { Patients with } \\
\text { periodontitis } \\
\text { and diabetes } \\
\text { undergoing } \\
\text { periodontal } \\
\text { therapy }\end{array}$ & $\begin{array}{l}\text { Periodontal disease: a } \\
\text { multi-factorial infectious } \\
\text { disease of the soft } \\
\text { tissues and bone that } \\
\text { support the teeth. } \\
\text { Individual studies } \\
\text { clinical parameters } \\
\text { presented }\end{array}$ & $\begin{array}{l}\text { periodontal therapies on } \\
\text { metabolic control in T2DM } \\
\text { patients with PD } \\
\text { Covariates adjusted none } \\
\text { presented }\end{array}$ & $\begin{array}{l}\text { 1. After the follow-up of } 3 \\
\text { months, treatment substantially } \\
\text { lowered } \mathrm{HbA} 1 \mathrm{c} \text { compared with } \\
\text { no treatment after periodontal } \\
\text { therapy }(-0.36 \%, 95 \% \mathrm{Cl} \text {, } \\
0.52 \% \text { to } 0.19 \%, \mathrm{P}<0.0001) \\
\text { 2. Clinically substantial and } \\
\text { statistically significant reduction } \\
\text { of PPD and CAL were found } \\
\text { between subjects with and } \\
\text { without treatment after } \\
\text { periodontal therapy (PPD } 0.42\end{array}$ & $\begin{array}{l}\text { Periodontal treatment leads to the } \\
\text { modest reduction in HbA1c along with } \\
\text { the improvement of periodontal status } \\
\text { in diabetic patients for } 3 \text { months, and } \\
\text { this result is consistent with previous } \\
\text { systematic reviews, and the effect of } \\
\text { periodontal treatment on } \mathrm{HbA} 1 \mathrm{c} \text { cannot } \\
\text { be observed } 6 \text {-months after treatment }\end{array}$ & $\begin{array}{l}\text { Amstar not met: } \\
\text { No priori design, } \\
\text { no duplicate study } \\
\text { selection, } \\
\text { No status of } \\
\text { publication in }\end{array}$ \\
\hline
\end{tabular}




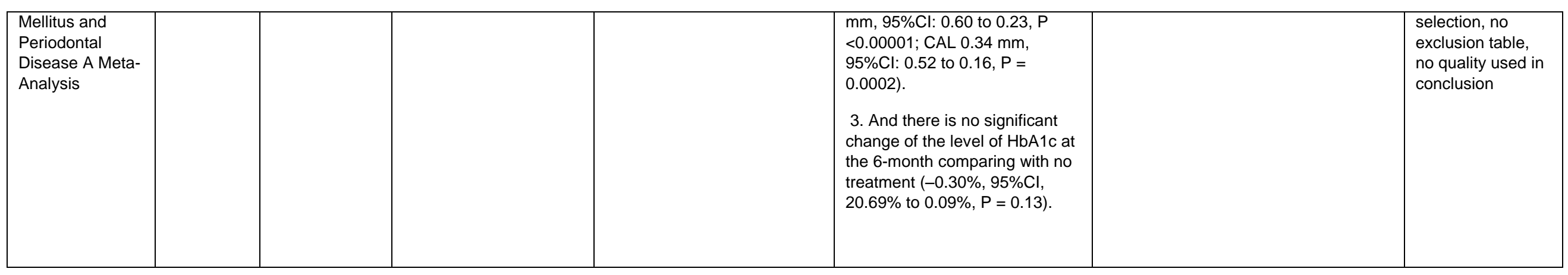




\section{Table 2: Key Questions}

\begin{tabular}{|c|c|}
\hline & Key Questions to be addressed \\
\hline$\bullet$ & Is diabetes associated with an increased risk of periodontitis and vice versa? \\
\hline$\bullet$ & Is Type 1 diabetes associated with an increased risk of caries and vice versa? \\
\hline & $\begin{array}{l}\text { Does regular periodontal care (e.g. } 3 \text { monthly scaling and root planing sessions) } \\
\text { improve glycaemic control and reduce incidence of complications in patients with } \\
\text { diabetes? }\end{array}$ \\
\hline & $\begin{array}{l}\text { What is the impact of common oral diseases (periodontitis and caries) and their } \\
\text { management on patient-reported outcomes (e.g. quality of life) relevant to diabetes? }\end{array}$ \\
\hline & $\begin{array}{l}\text { What is the incidence and risk of infectious complications in patients undergoing dental } \\
\text { treatment and who have diabetes. }\end{array}$ \\
\hline
\end{tabular}

